I 19.2:G29/14

\title{
U.S. GEOLOGICAL SURVEY NATIONAL CENTER RESTON, VIRGINIA
}

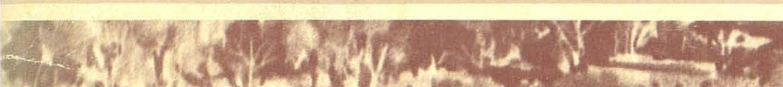

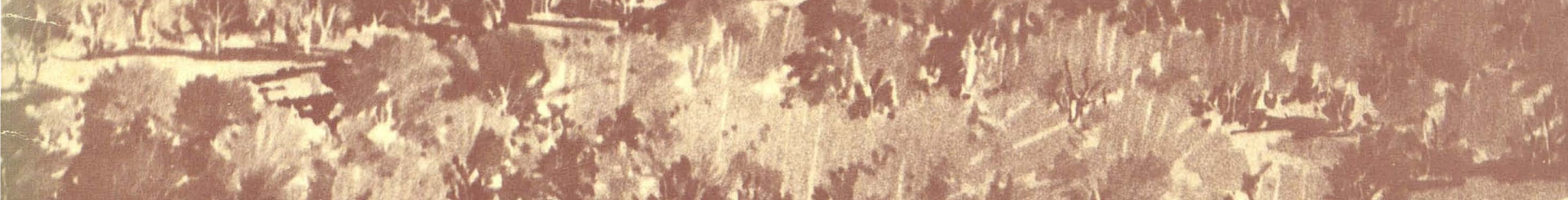

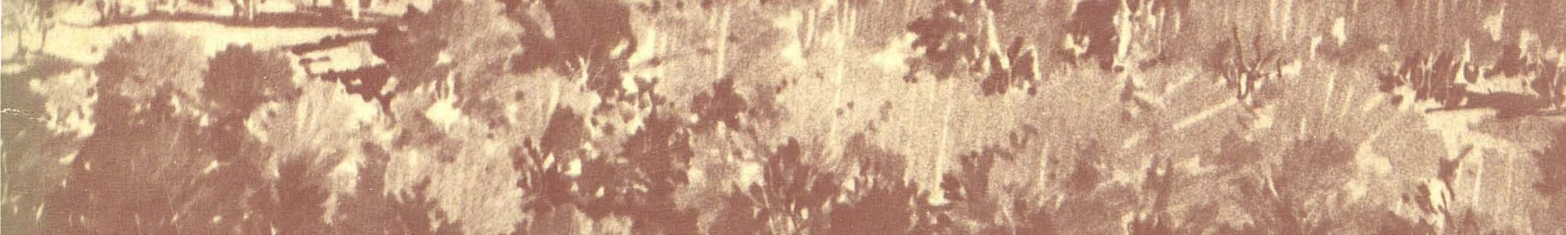

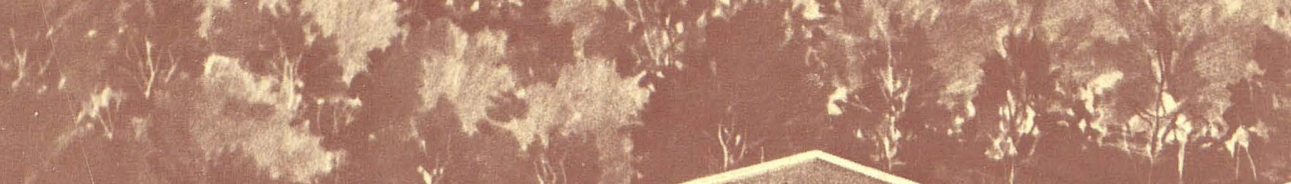
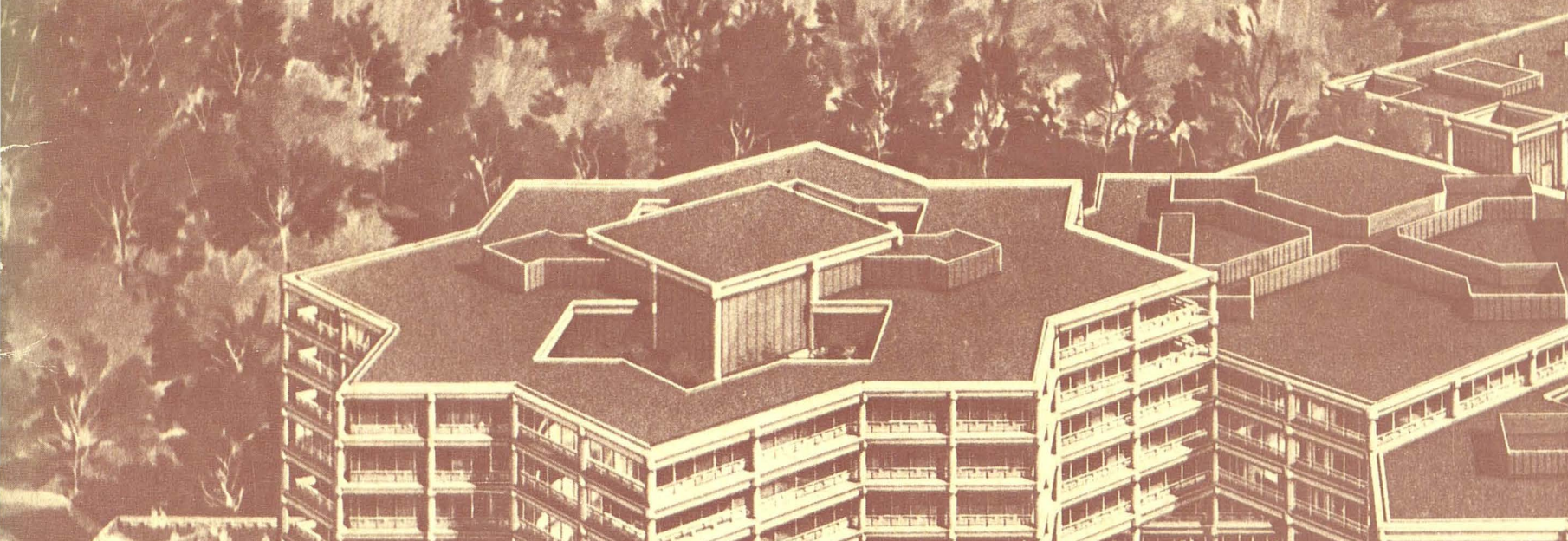

3. 







\section{U. S. GEOLOGICAL SURVEY NATIONAL CENTER RESTON, VIRGINIA}

2 BACKGROUND INFORMATION

5 PRE-DESIGN STUDY

7 SITE

Selection

Description

Vehicular Access

Clearing

Technical Easements

13 DESIGN

Architectural Finish : Exterior

Architectural Finish: Interior

Structural and Mechanical Details

16 SPACE USE BY AREAS

Administrative Area

Laboratory Area

Map Reproduction Area

17 SPACE USE BY FLOORS

This report provides a description of the U. S. Geological Survey National Center at Reston, Virginia, and a record of events leading to its construction. 


\section{U.S. GEOLOGICAL SURVEY NATIONAL CENTER RESTON, VIRGINIA}

\section{BACK GROUND INFORMATION}

In 1917 the Geological Survey moved into the newly built Interior Building near the White House in Washington, D. C. Twenty years later a larger building was constructed nearby to house the expanding U. S. Department of the Interior. Height restrictions reduced the planned size of the new building, and the Geological Survey was compelled to remain in the older Interior Building now identified as the General Services Administration Building. Expansion of the Survey's programs, and particularly the overall government need for additional office space in downtown Washington, has resulted in the Survey's activities being presently housed in 30 different buildings, at 17 widely scattered locations throughout the Washington Metropolitan Area.

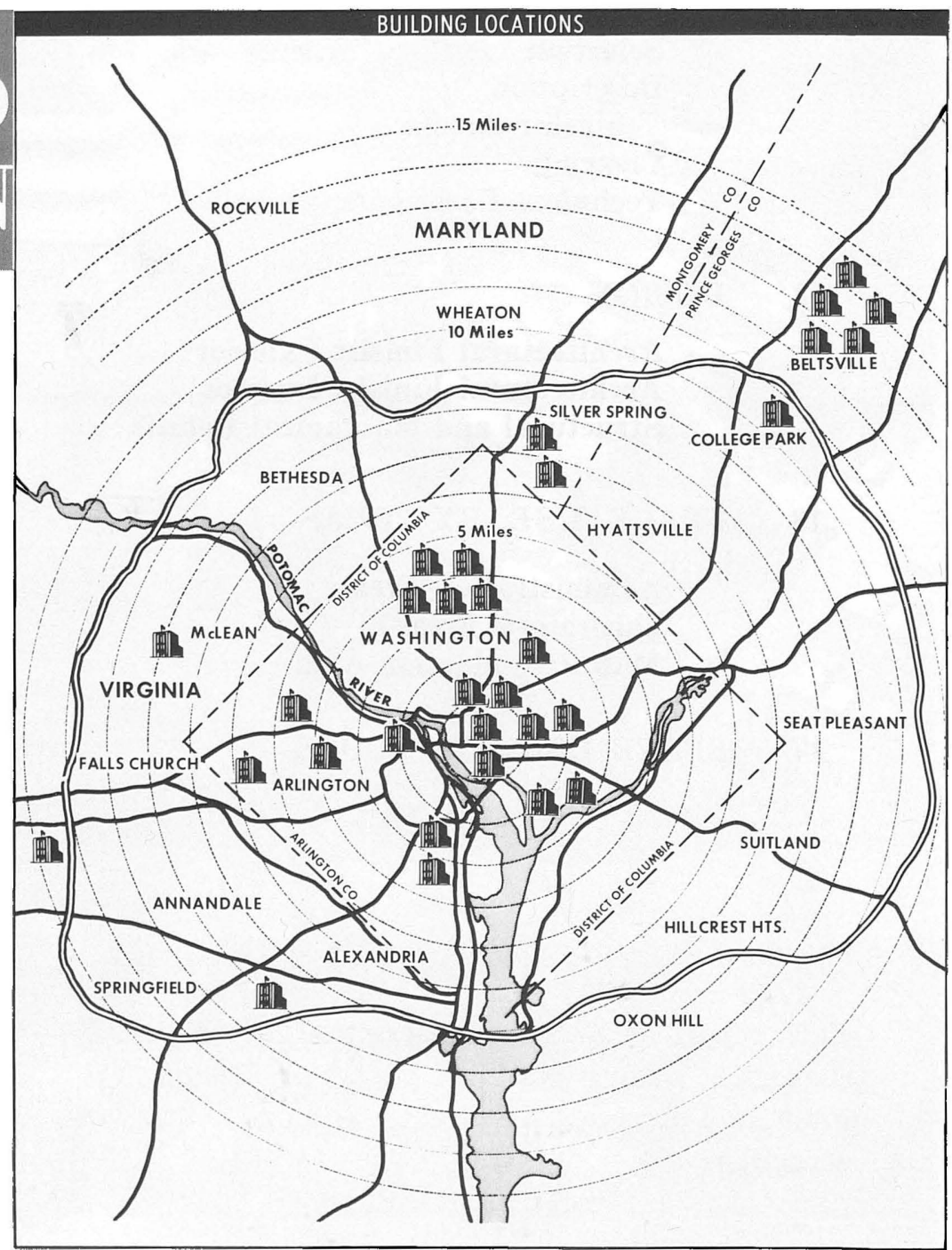




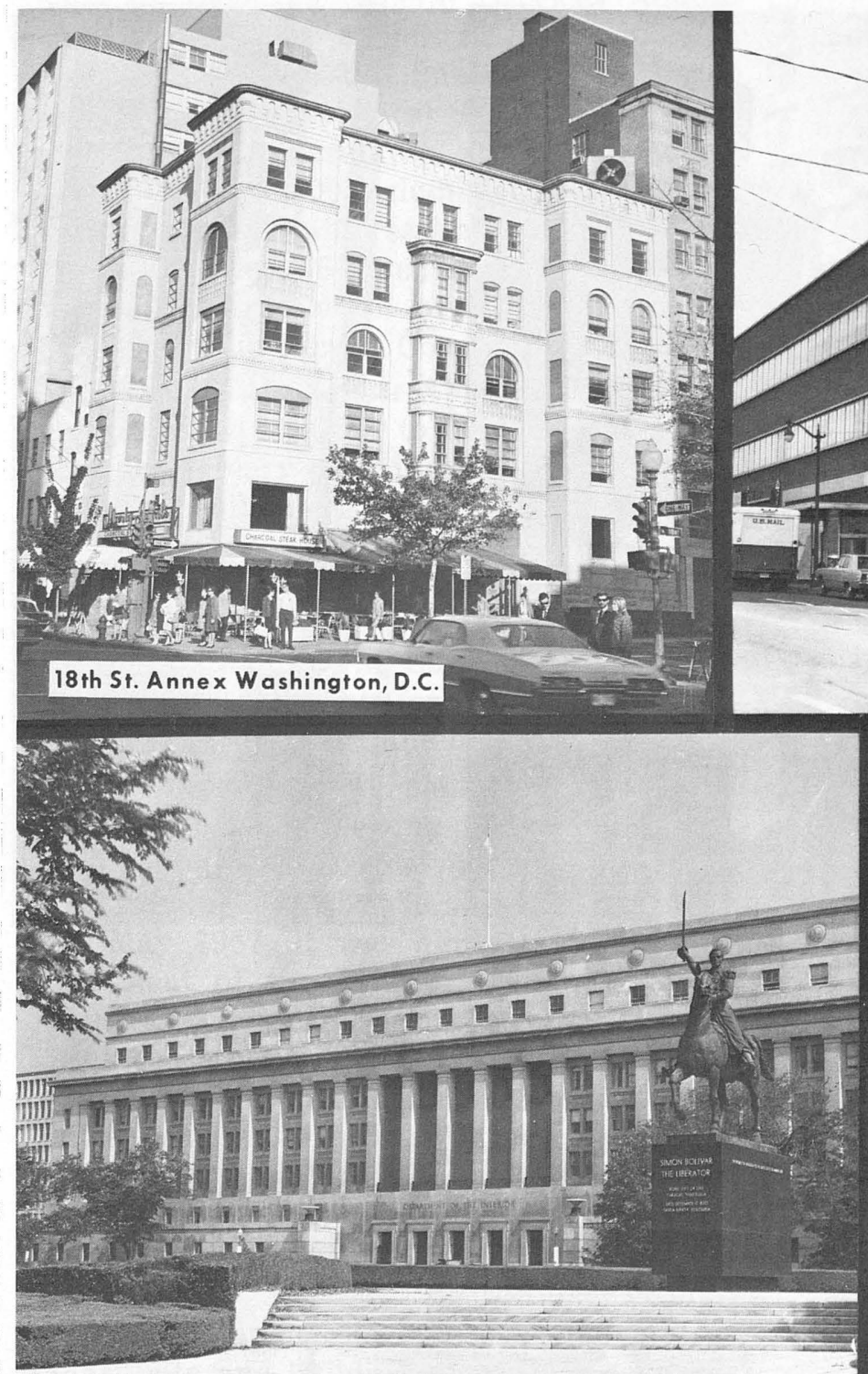

Interior BIdg. Washington, D.C.

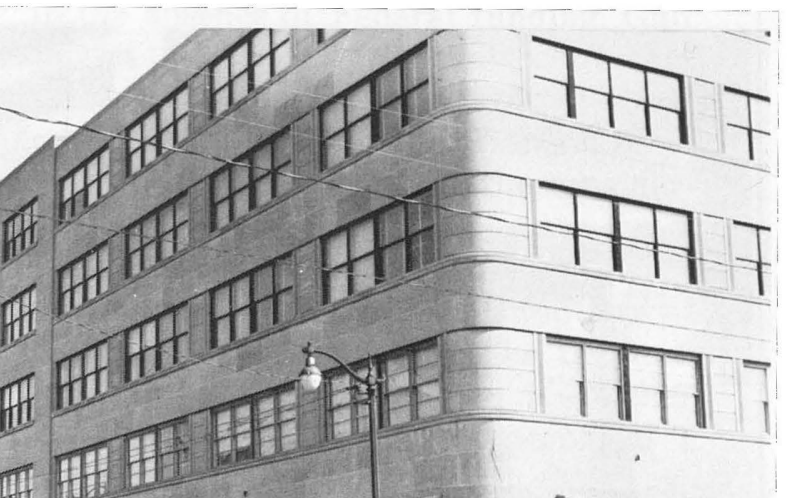

(

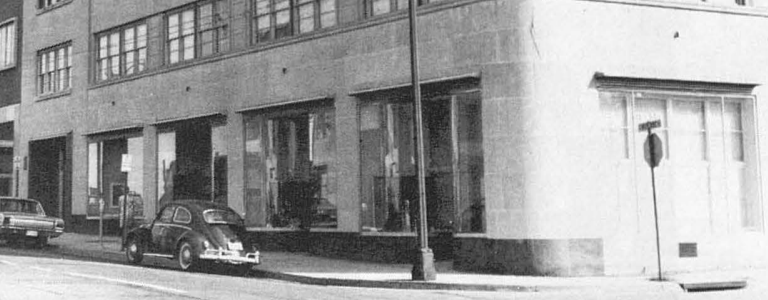

Old Dominion Bldg. Arlington, Virginia

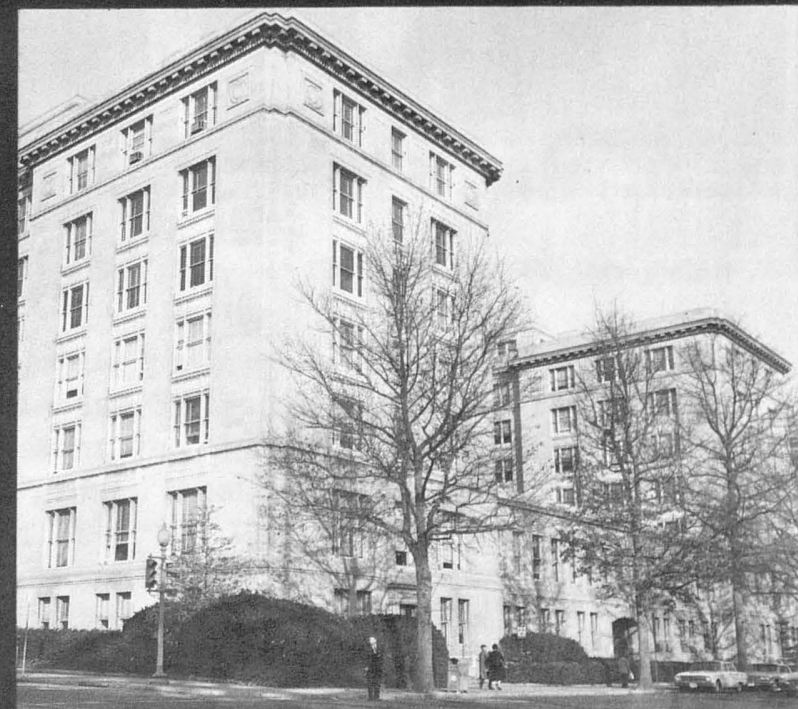

GSA BIdg. Washington, D.C.

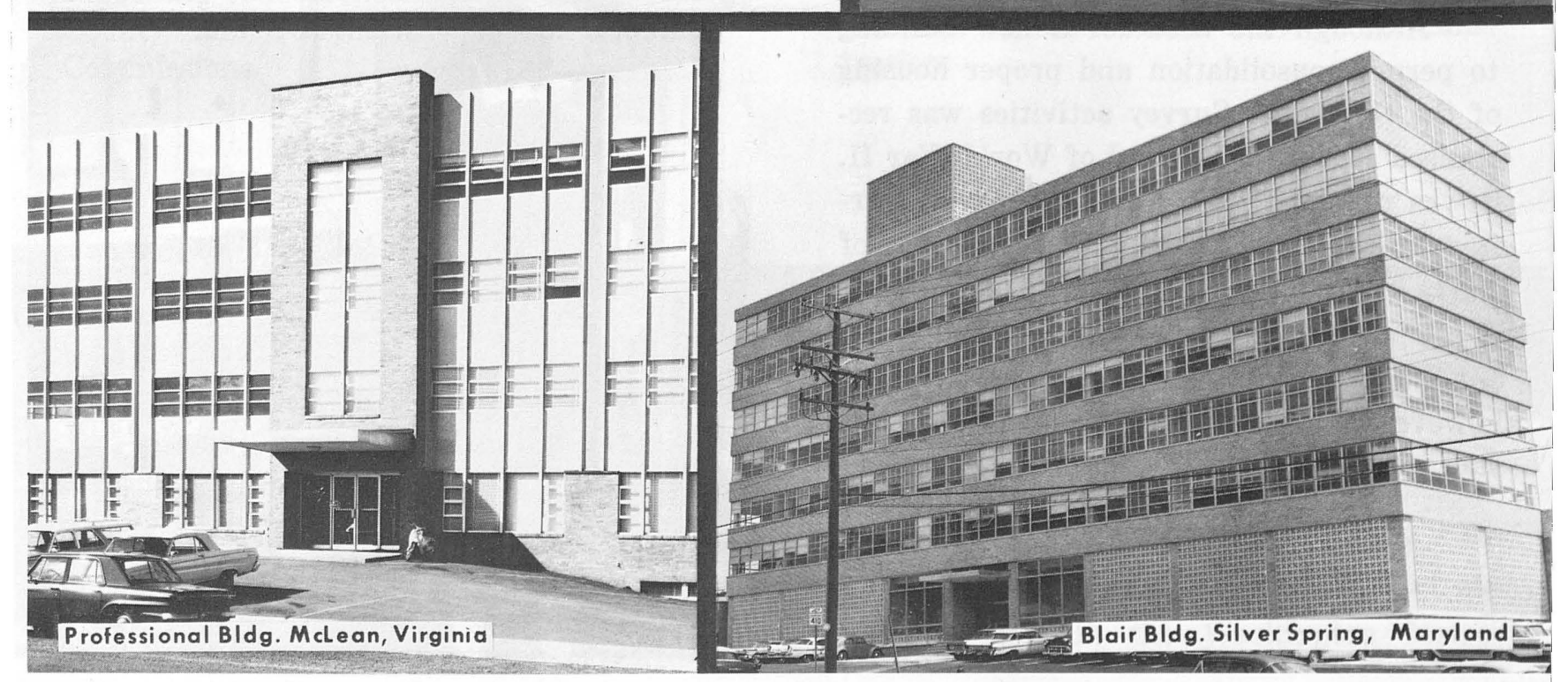



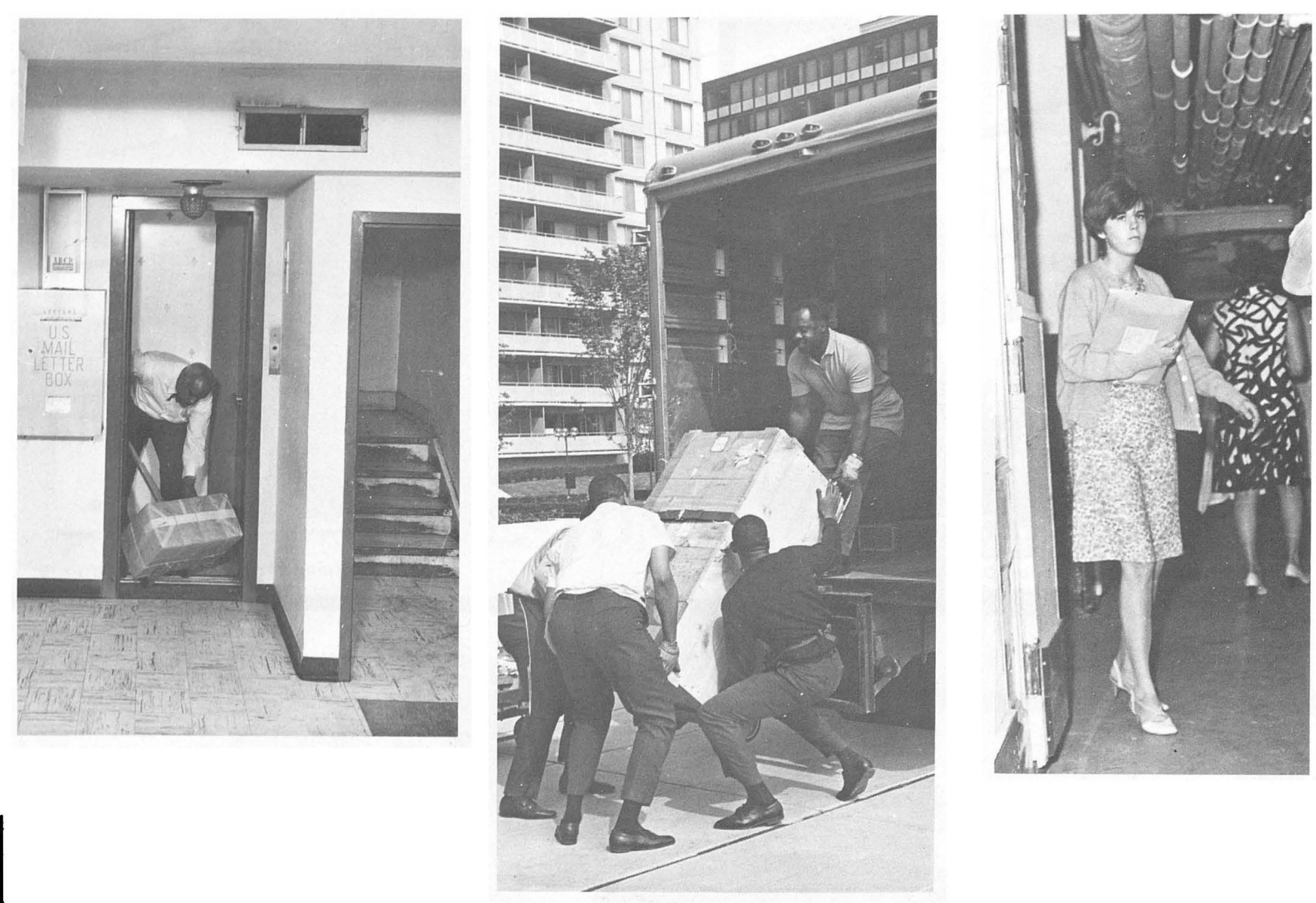

Although the need for a new building to permit consolidation and proper housing of the Geological Survey activities was recognized soon after the end of World War II, it was not until 1956 that Congress authorized, under the Purchase Contract Act of 1954, a building to be constructed on Federally owned land within the District of Columbia. No suitable site was available, however, and the Purchase Contract Act subsequently expired.

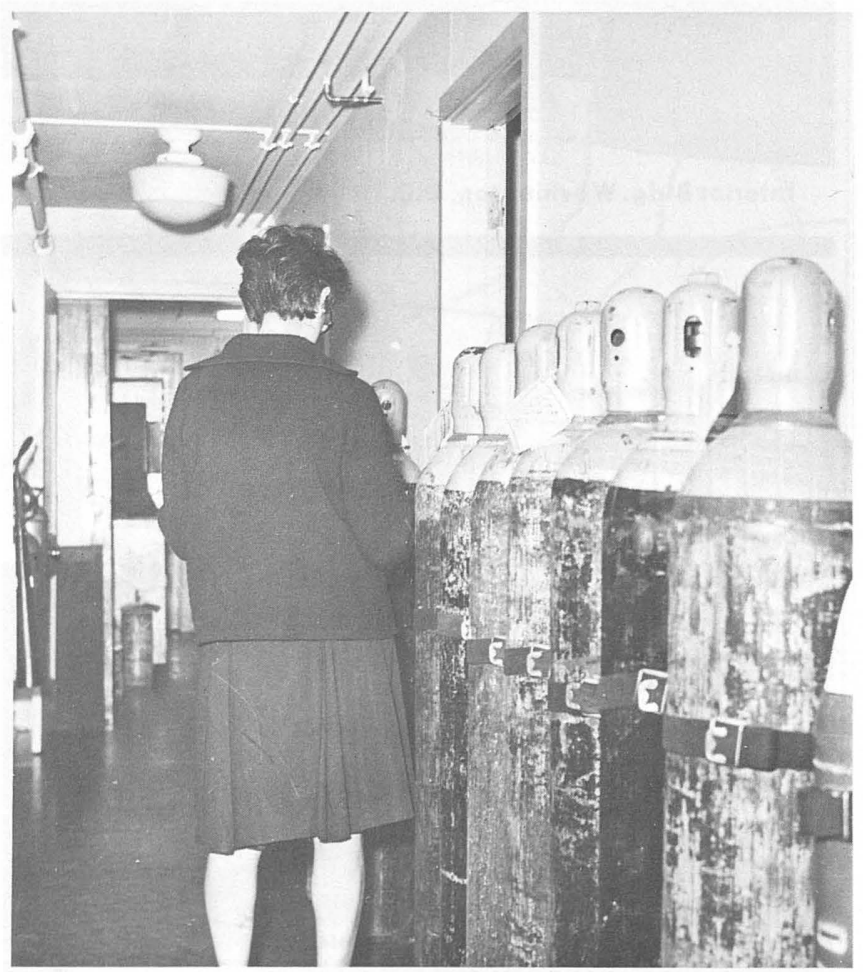


In 1959 the General Services Administration (GSA) submitted to Congress a prospectus under the Public Buildings Act of 1959 for a Geological Survey building of 603,700 net square feet, at a total project cost of $\$ 32,240,000$ including site and design. The prospectus was resubmitted to Congress unchanged in 1961, and in 1962 it was approved by resolution of both Senate and House Public Works Committees.

In 1964 the Senate Appropriations Committee added $\$ 100,000$ to the Survey's budget for preliminary planning and site study for the new building. This gave the project the necessary momentum and in the same year Congress provided $\$ 2,025,000$ to GSA for site acquisition and design of a Geological Survey building. The Survey appropriation of $\$ 100,000$ was transferred to GSA providing them a working fund of $\$ 2,125,000$.

Throughout the planning period, described in the following in greater detail, there was considerable discussion concerning funding of the building construction. In May 1967, it was agreed that the Department of the Interior, rather than the General Services Administration, would seek construction funds in the 1969 budget. Budgetary restraints at this time led to serious consideration of splitting construction into two phases, to permit an early start on the foundation with the superstructure to follow.

On July 27, 1967, the National Capital Planning Commission approved the preliminary site and building plans, and acknowledged the concurrence of both the Fairfax County and Northern Virginia Planning Commissions.
In the absence of Federal funding, Gulf Reston, on April 25, 1968, proposed that they construct the building with private funds and lease it to the Government for a period of 20 years. In view of the considerably increased cost and change in the funding plans, a revised prospectus was prepared and sent to the Public Works Committees of Congress on January 6, 1969. The Committees approved the prospectus in May 1969, giving GSA the authority to negotiate a lease construction agreement with Gulf Reston. On September 12, 1969, while this agreement was being negotiated, a temporary deferral was imposed on 75 percent of the authorized and funded Federal construction and the Survey project was included in this 75 percent. In May 1970, the Bureau of the Budget authorized GSA to proceed with the Survey project and on August 13, 1970, the lease agreement with Gulf Reston was signed.

Competitive construction bids were invited on September 28, 1970, and received January 18, 1971.

The George H. Hyman Construction Company of Washington, D. C., submitted the low bid and on June 29, 1971, was awarded the construction contract by Gulf Reston, Inc., in the amount of $\$ 44,118,000$. A ground breaking ceremony was conducted on July 31, 1971, with Secretary of the Interior Rogers C. B. Morton turning the first earth.

Construction started immediately and is scheduled for completion in January, 1974.

The lease construction is under the direction of the General Services Administration.

\section{PRE-DESIGN STUDY}

On June 29, 1964, the architectural firms of Skidmore, Owings and Merrill of Chicago, Illinois, and H. D. Nottingham \& Associates of Arlington, Virginia, were awarded a contract by the General Ser- vices Administration to make a pre-design study of the Geological Survey's requirements including the evaluation of six possible sites in the Washington Metro- 
ROOM LAYOUT CHART

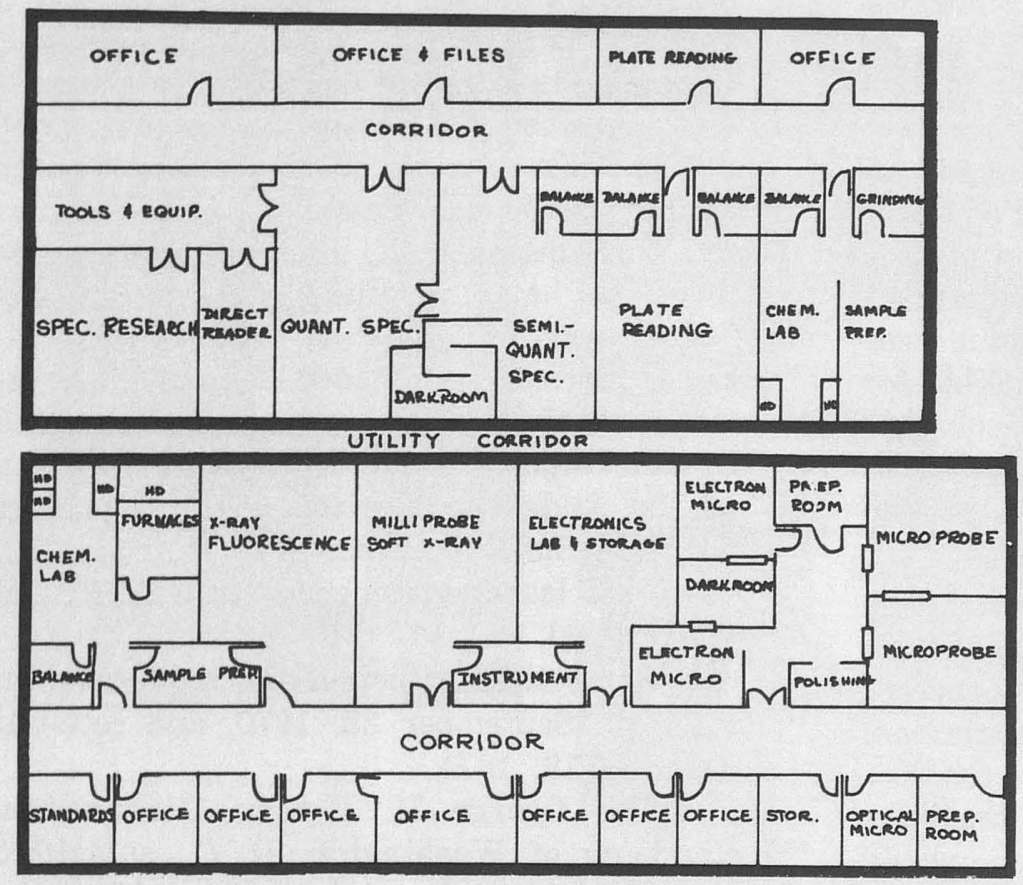

politan Area. Mr. Robert H. Lyddan, then Assistant Director for Engineering, headed a committee of Division representatives who provided data on Survey programs, space needs, and special requirements to the architects. This study was completed on February 22, 1965.

Total space required exceeded the 603,700 net square feet authorized in the 1959 prospectus by some 150,000 square feet and the decision was made to defer relocation of the Map Distribution facility and a portion of the $\mathrm{Pa}$ leontology and Stratigraphy unit located at the National Museum until a later date.

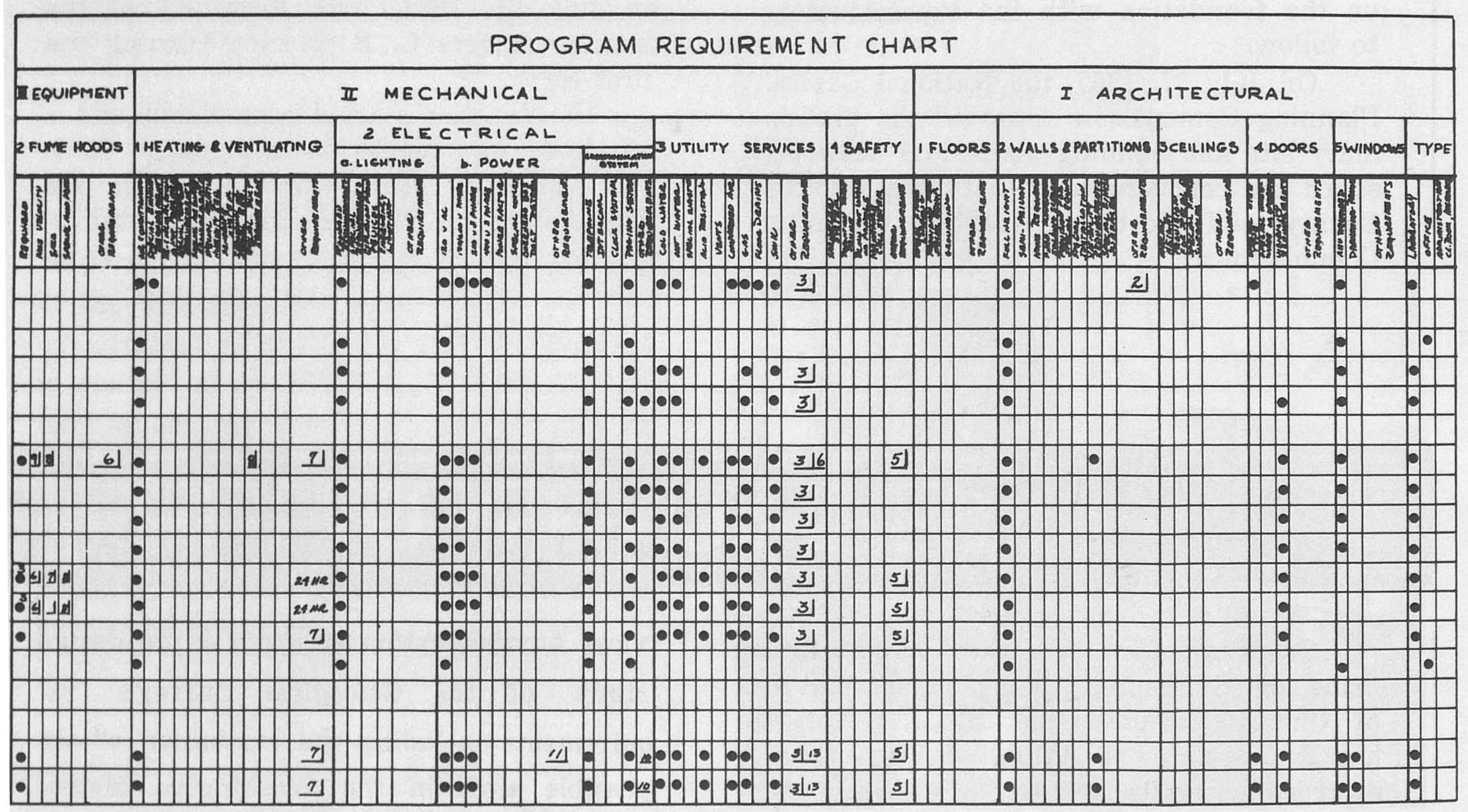




\section{SELECTION}

During 1965 the Survey made an intensive analysis of the architects' evaluation of the six possible sites in and around Washington. These included the National Training School for Boys in Washington; Suitland
Hall in Prince Georges County, Maryland; Congressional Manor and Gold Mine sites in Montgomery County, Maryland; Bureau of Public Roads, and an area in the newly developing town of Reston in Fairfax County, Virginia.

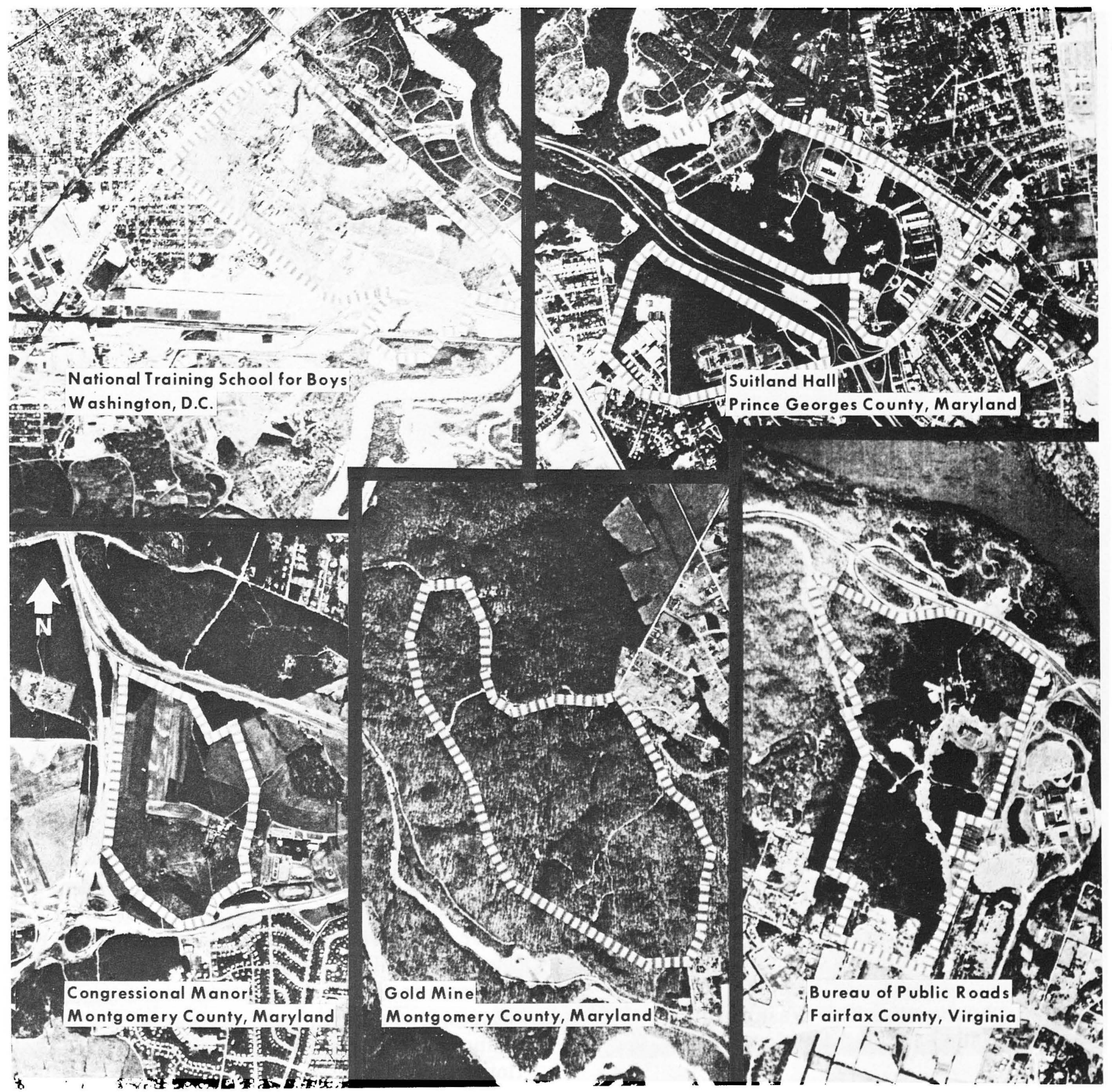




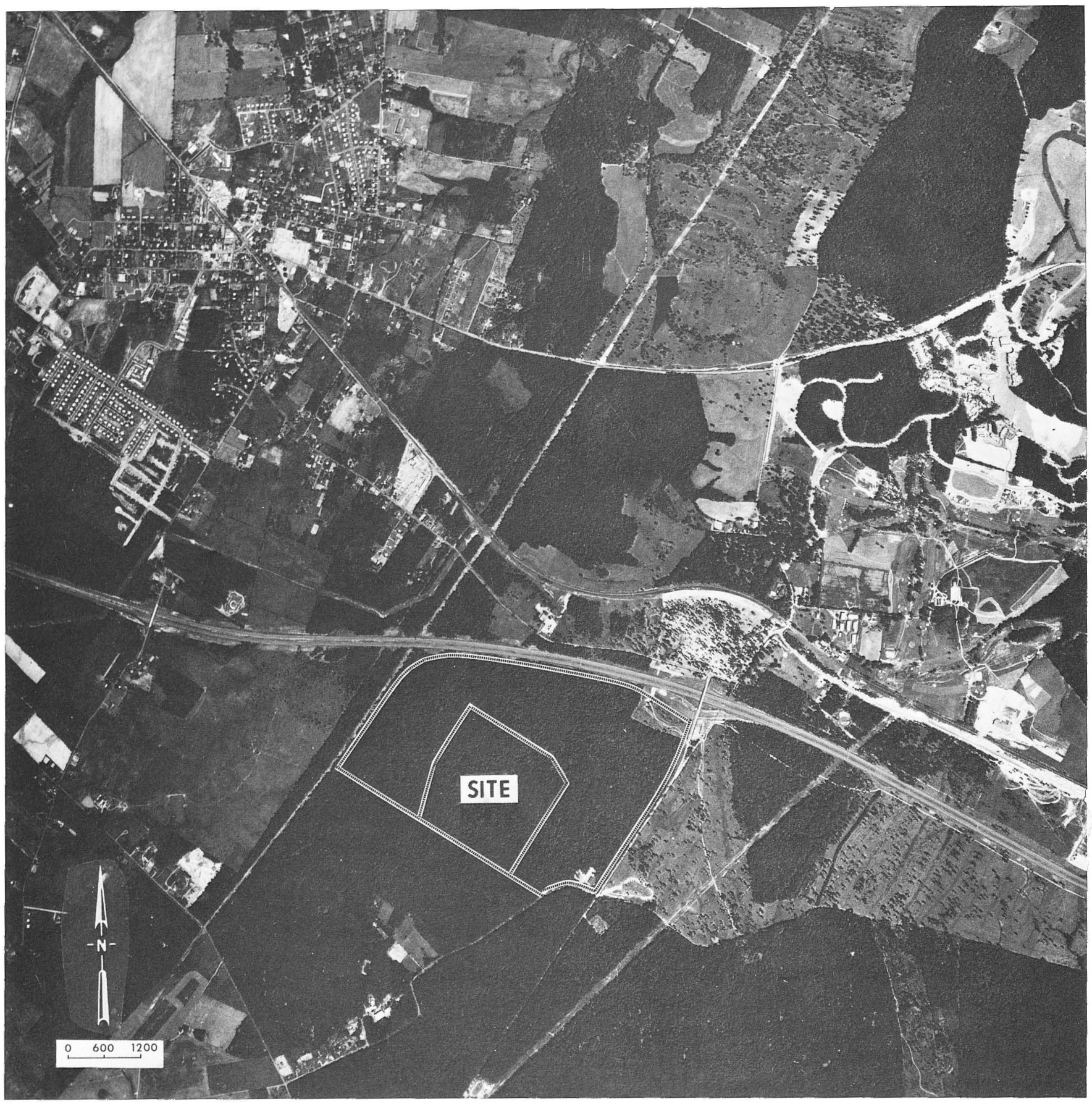

On February 1, 1966, a site within the town of Reston was selected by the Secretary of the Interior as the most desirable location of those available to the Geological Survey.

Reston comprises 7,400 acres, some $111 / 2$ square miles of Virginia countryside, lying 18 miles west of Washington, D. C., in the rolling hills of Fairfax County, Virginia.
Included in Reston's design are provisions for a wide range of facilities and services for housing, churches, public and private schools, medical services, libraries, community centers, village centers, a town center, research facilities and industriai complex, public transportation, banking and business facilities, and parks, lakes, golf courses, swimming pools, walkways, trails, riding facilities and other desirable recreational facilities. 
On February 3, 1966, the General Services Administration signed a contract with the architectural firms of Skidmore, Owings, and Merrill, and H. D. Nottingham and Associates for a more detailed development study of the Reston site and design of the new National Center.

The site study was completed in April 1966. It was reviewed by the Survey and the General Services Administration, and approved by the National Capital Planning Commission on July 28, 1966.

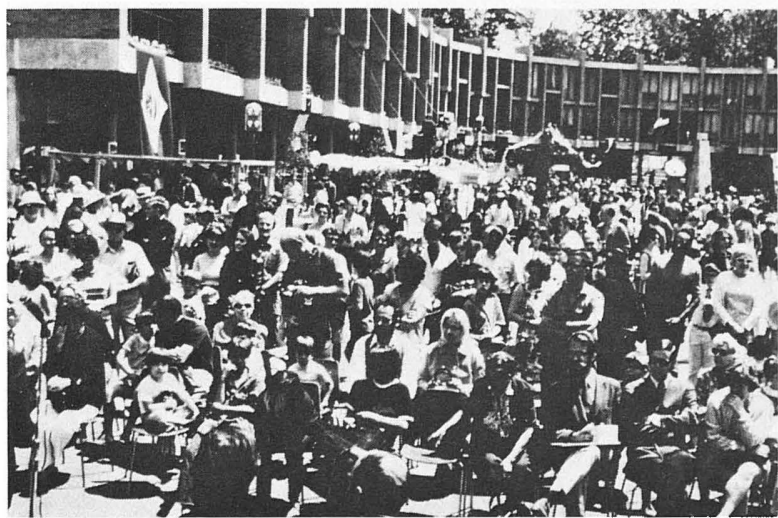

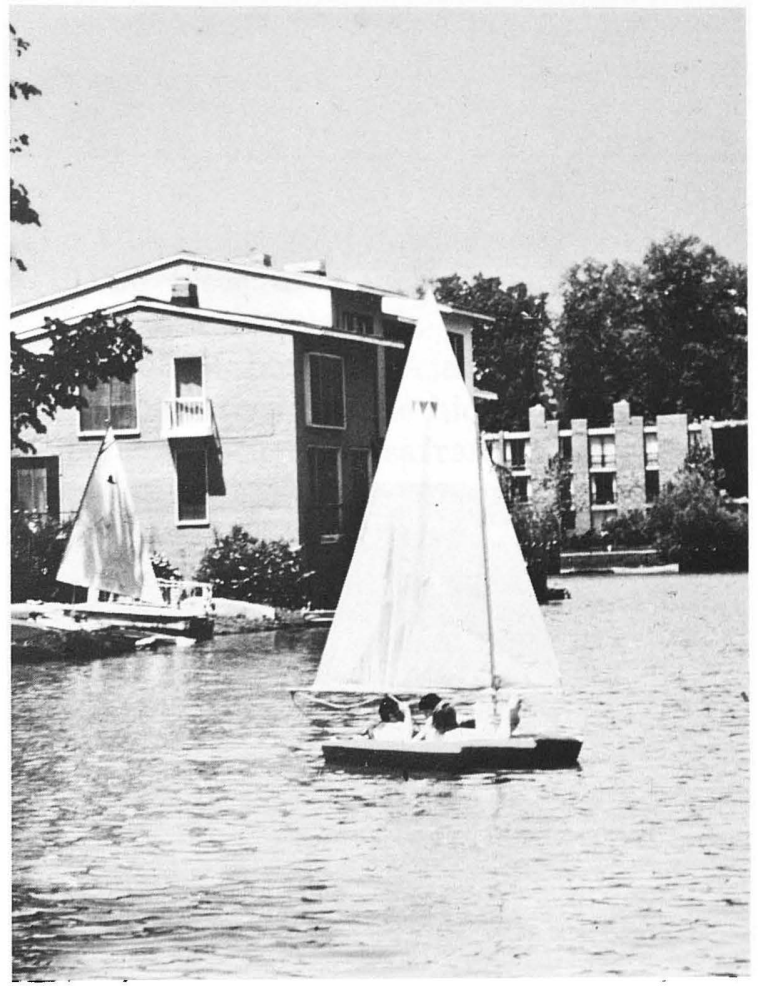
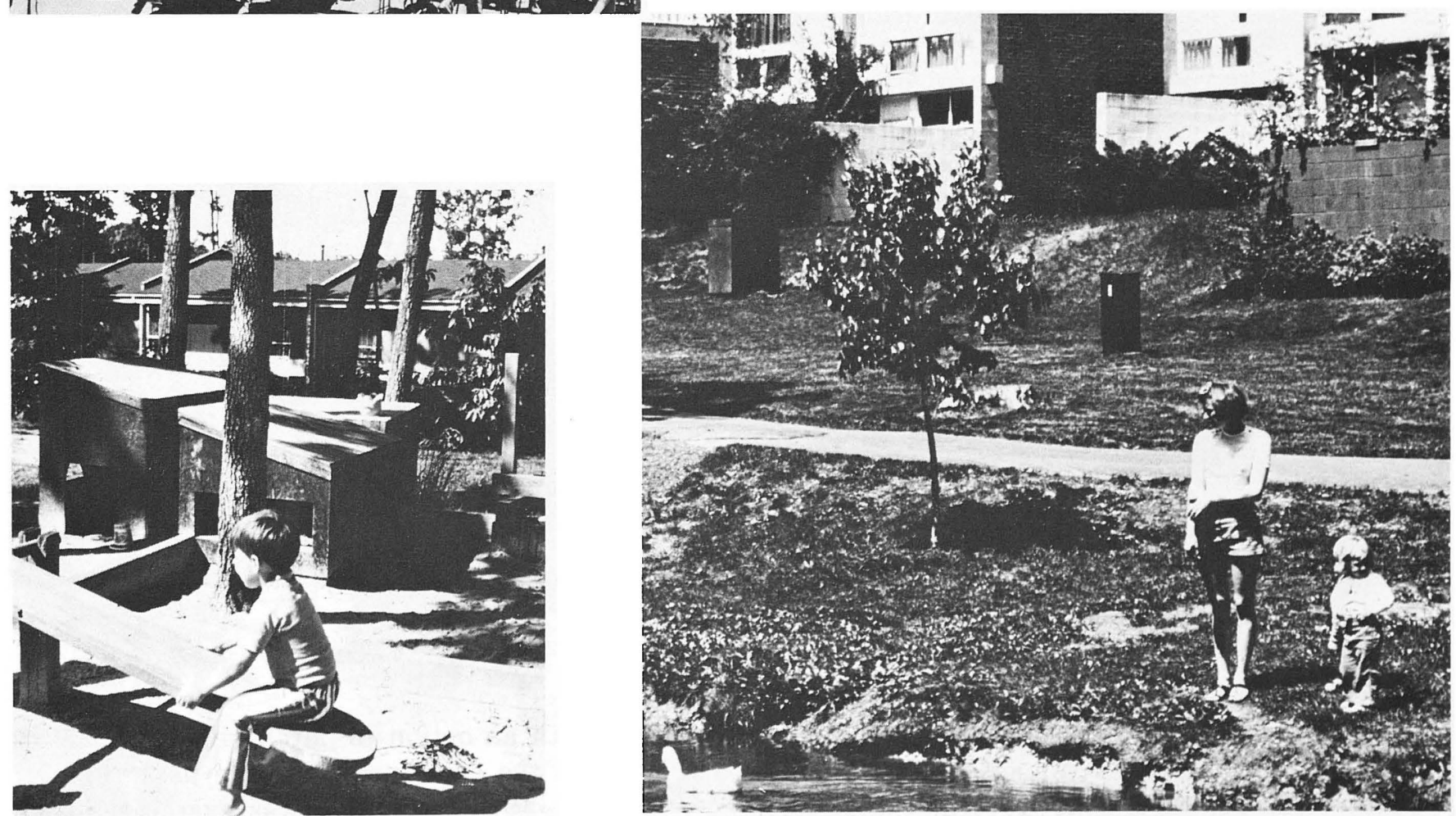


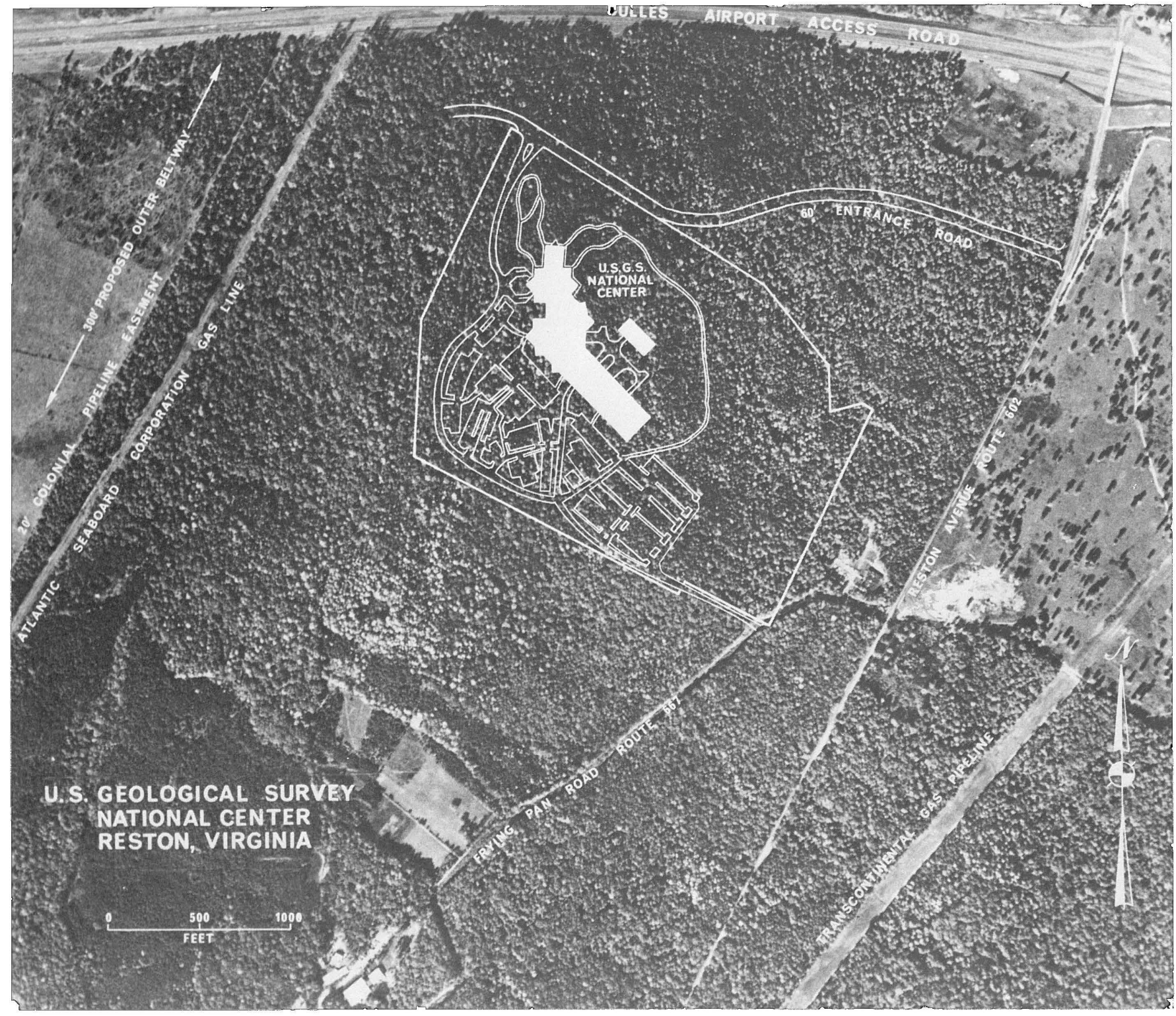

Negotiations for the site, which were completed August 5, 1966, resulted in a 50acre gift to the Government from Reston and the purchase by the Government of an additional 35 adjoining acres at $\$ 7,000$ per acre, with an option to purchase another 20 acres at the same price for the next three years. In 1969 the option was exercised increasing the total site to 105 acres. 


\section{DESCRIPTION}

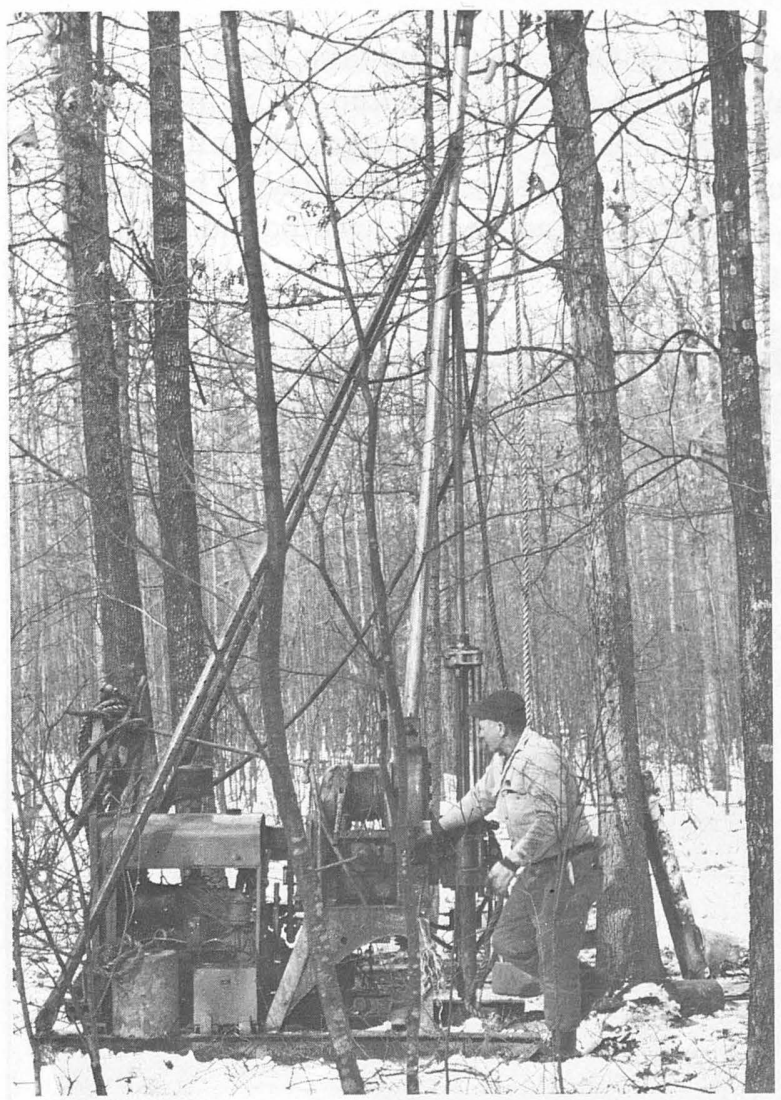

The site is heavily wooded, containing some 10,000 trees of 8-inch diameter or over. Trees are mostly oak, including red, white, pin, black, post, blackjack and chestnut oak. Other trees include hickory, maple, beech, poplar, locust, sassafrass, dogwood, and gum. Holly shrubs are present, and also groundcovers such as partridge berry, pipsissewa, and tree-club mosses.

The site is underlain largely by Triassic Manassas Sandstone, which in this area consists of scattered pebbles of schist, sandstone, and quartz in a matrix of red or purple micaceous, silty sand. Adjacent formations are Triassic diabase to the west and early Paleozoic Wissahickon Schist to the east.
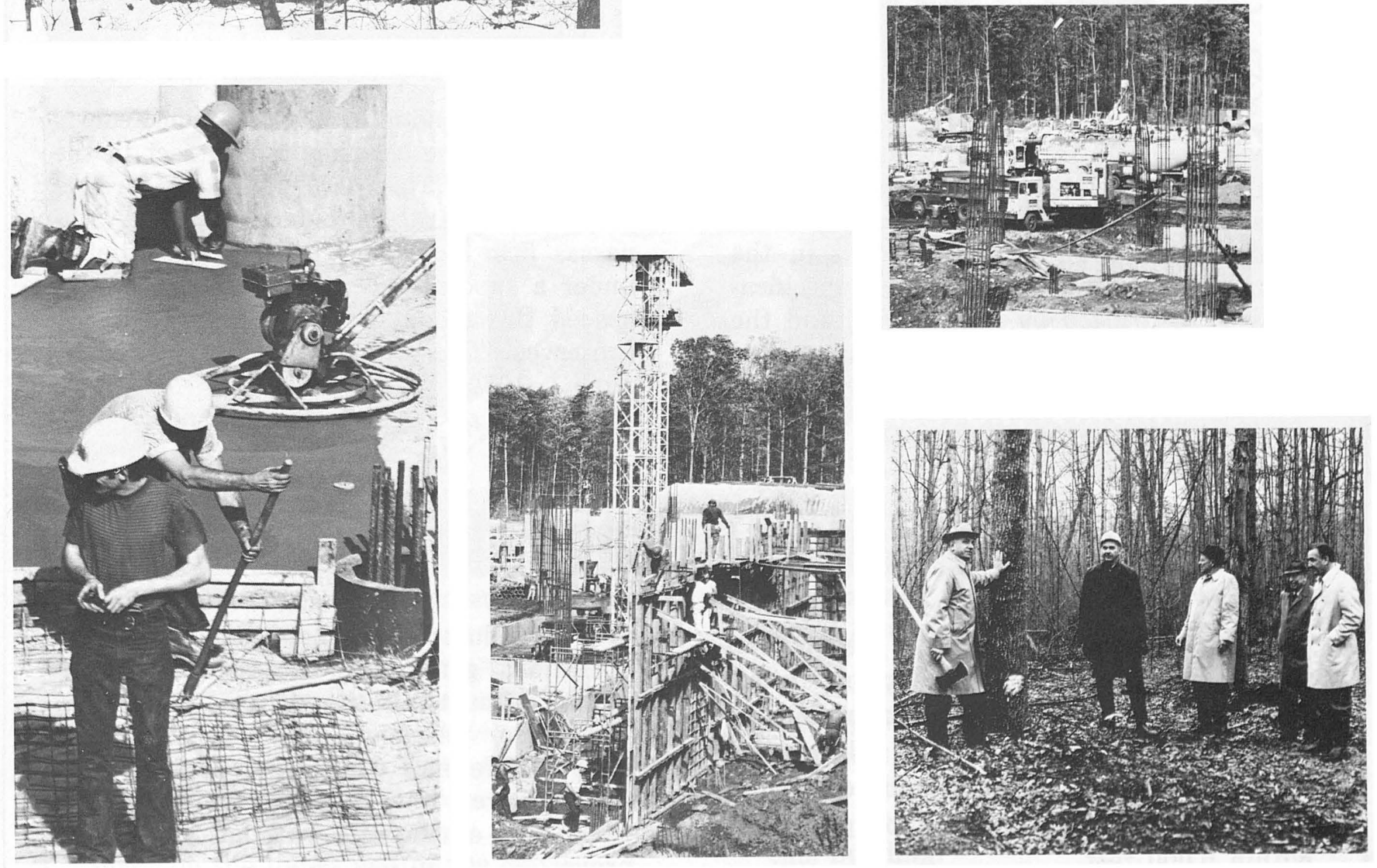
The new National Center will be within 2 miles of two of the proposed five "villages" of Reston-Lake Anne and Hunters Woods. Lake Anne Village was completed in 1968 and construction of Hunters Woods was started in the spring of 1970 . The Reston Master Plan indicates a population of about 15,000 for each village, with a variety of housing types and prices.

The Survey building will be located about 2,500 feet southwest of the intersection of Reston Avenue (State Route 602) and the Dulles Highway. Present access is north from U. S. Highways 50 and 66 over State Routes 665,602 , and 608 or west and south from State Route 7 over State Routes 606 and 602.

State Route 606 is being widened to four lanes from State Route 7 to State Route 602. Gulf Reston has assured that Reston Avenue will have four lanes within the boundaries of Reston. It is essential to the project that this four-lane road be continued south to U. S. 50 and U. S. 66. This is in the State's long range planning, but construction must be accelerated. The right of access to Reston by westbound Dulles Highway traffic by means of an interchange in the vicinity of Reston Avenue would be most advantageous. Ramps have been constructed to permit Reston traffic to use Dulles Highway for travel to and from the airport. Reston traffic cannot, however, enter Dulles Highway eastbound or exit from the Highway westbound. The Federal Aviation Agency has agreed to provide at no cost to the State of Virginia a right of way paralleling the Dulles Highway anytime the State is ready to build a parallel road accessible to developments along its route. Access to Reston Avenue from the site will be over four-lane paved roads from the northwest and southeast corners of the site.

\section{CLEARING}

While construction of the Survey project was included in the 75-percent deferral of all Federal construction, it was decided to advance the project by clearing trees from the 45 acres of the site within the construction boundary. Plans and specifications were drafted by the Survey, and the General Services Administration negotiated an agreement with Gulf Reston whereby
Gulf Reston administered a non-Federal contract for the clearing. A contract in the amount of $\$ 25,975$ ( $\$ 577$ per acre) for this work was awarded in March 1970. A Manassas firm logged off much of the timber under a subcontract. Eight clumps of trees spaced throughout the Parking Areas were preserved. The clearing was completed on June 1, 1970.

\section{TECHNICAL EASEMENTS}

The National Center will require an environment free of air pollution, interferences and vibration. No manufacturing or processing operations which release particulate matter into the atmosphere through exhausts or smokestacks will be permitted within 5,000 feet.
No industrial, mechanical or quarrying operations generating excessive vibrations will be permitted in the vicinity.

Radio, television, and telecommunications interference will be restricted and no major power lines can be located within 1,000 feet of the site without Survey approval. 
At the outset serious consideration was given to a campus-type plan involving separate buildings for either each Division or a grouping of associated activities. The Reston site because of its size and natural characteristics could easily accommodate a campus-type installation. However, in further studying the program of requirements, the Architect-Engineers determined that the Survey's needs could be most efficiently housed in a single structure.

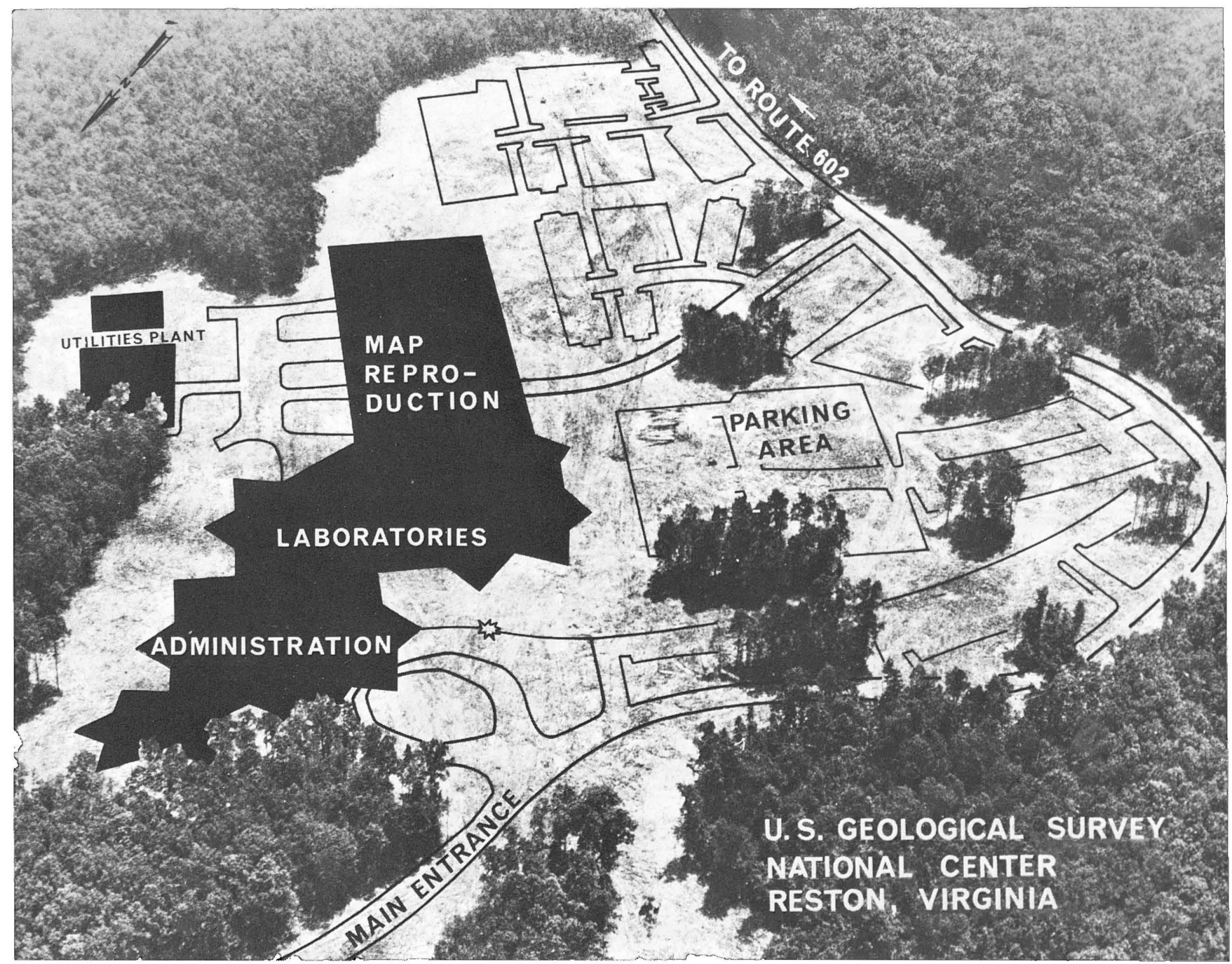

The National Center will be one continuous structure about 1200 feet long, built along a low ridge extending through the site. Although it is one structure, it can be considered as consisting of three Sections, namely the Administrative, Laboratory, and Map Reproduction Areas. The building height varies from about 120 feet in the seven-story Administrative Area to about 25 feet in the single story printing plant on the upper end of the ridge.
The $1,000,000$ square-foot building is planned to accommodate about $2500 \mathrm{em}$ ployees with parking facilities for 1600 vehicles in a series of surface lots.

A two-story central Utility Plant 110 feet by 180 feet in size is located 200 feet northeast of the headquarters building. It houses the heating and ventilating equipment. Cooling towers will be adjacent to this building. 


\section{ARCHITECTURAL FINISH: EXTERIOR}

The architecturally precast. concrete including exposed columns, typical window wall panels and terrace handrails will be a natural buff color. Mullions and window frames will be satin black extruded aluminum. The Cafeteria and first floor will have a clear plate glass floor-to-ceiling window wall with neutral gray, medium tint, light controlling glass for all other floors.

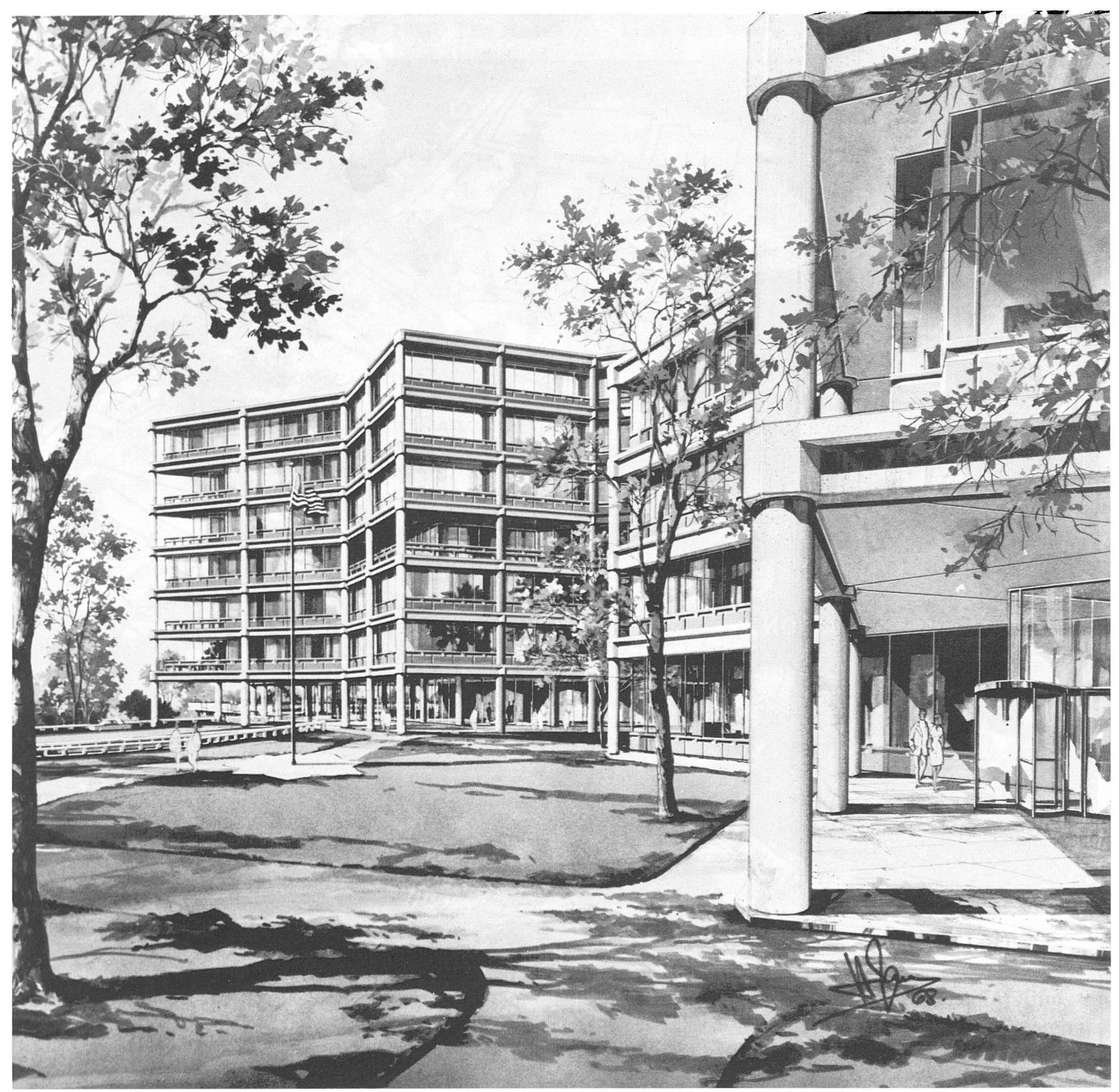

The mechanical penthouse, printing plant and central Utility Plant will have steel wall panel exteriors with satin black, porcelainized, stucco embossed enamel finish.
Landscaping will include the planting of some 900 trees and 15,000 plants throughout the 45 acres which have been cleared for the buildings and parking. 


\section{ARCHITECTURAL FINISH: INTERIOR}

Painted columns on most floors and fancoil covers will be medium light gray.

Except for the Administrative Area and certain other areas which will be carpeted, floors will be surfaced with vinyl asbestos tile. Ceilings will be acoustical tile.

Carpet colors will be as follows:

Gray for floors $1,6, \& 7$

Green for floor 2

Brown for floors 3 \& 4

Blue for floor 5
Doors and trim will be painted offwhite for floors one through six; on the seventh floor they will be natural chestnut.

All blinds will be vertical and light gray in color.

Terrazo lobby floors will be gray and walls will be light gray.

Vinyl tile throughout lab areas will be one of three shades of gray.

\section{STRUCTURAL AND MECHANICAL DETAILS}

The building structure will be a reinforced concrete framework of beams and columns. Exterior walls will be precast concrete panels set back from the exterior columns. This set back recesses the 6-foot high, tinted glass windows and provides exterior services walkways on each floor. Interior areas will be subdivided by gypsum board and metal stud partitions.

Each floor of the structure consists essentially of a series of 200-foot square modules superimposed on 212-foot square modules and rotated $45^{\circ}$. This provides a floor with as many as 16 sides which develops considerably more exterior window space than would be available with either a square or rectangular structure.

The variable bay spacing reflects the orientation of the basic 5-foot module to the Administrative, Laboratory and warehouse-industrial spacing and structural loading requirements. Thus, the 25 -foot bays of the Administrative Wing can be varied to 35 feet, the diagonal of 25 , and in turn, the 35-foot bays appropriate to the Laboratories may be varied to 50 feet, the diagonal of 35, where special long spans are required.

On the first floor and in the basement it is 16 feet from top of floor slab to top of slab. On floors two through seven it is 13 feet from top of slab to top of slab. Normal ceiling height in offices and labs will be 9 feet 10 inches with the remaining space utilized for duct work and air conduction.

The complex contains a central elevator core of six elevators including one freight elevator in the Administrative Wing and three pairs of passenger elevators and one freight elevator in the Laboratories. There are 11 stairwells located throughout the building to provide emergency exit and quick communication between floors. Twelve Laboratory Service cores provide mechanical services to all lab floors. 
The entire building with the exception of the truck loading dock and first floor bulk Storage Areas is to be air conditioned.

Perimeter Office Areas in Laboratory and Office Wings will be served by a fourpipe fan-coil system with a separate onerow hot water coil and a three-row cooling coil. The fan-coil units will be of the 100percent recirculation type; ventilation air to perimeter areas will be supplied from side wall diffusers off of the interior systems. The Office Wing interior spaces are served by low velocity reheat systems.

Office Areas, conference rooms, drafting rooms, and other areas with relatively low air change will have air supply and return built into the light fixtures. Laboratories and other high air change areas will have square or rectangular standard ceiling diffusers and return air grilles.

Ceiling plenums are to be utilized for return air systems in all areas with officetype use, such as drafting rooms, conference rooms, Cartography rooms, computer rooms, offices, and corridors.

Air supply systems with mixed air temperatures above $50^{\circ} \mathrm{F}$ will not be provided with preheat coils; systems with mixed air temperature below $50^{\circ} \mathrm{F}$ will be provided with steam preheat coils, one row or two rows in series depending on temperature.
The first floor main Lobbies and Cafeteria are heated and cooled by low velocity reheat systems with air supplied from floor outlets at the perimeter glass line.

Air ventilation and humidity control for the Computer Facility is to be supplied from the interior system. A separate air handling unit with a chilled water coil will supply air in the computer floor plenum for cooling.

Fume hoods are to be of the by-pass type in continuous operation. Where fume hood exhaust requirements in specific Laboratories are excessive, induced-type hoods with a maximum of 70-percent non-air conditioned air introduced directly into the hood, have been utilized to reduce the amount of air required and to reduce the possibility of drafts in the space.

Laboratories with excessively high heat loads are to be furnished with 100-percent recirculation fan-coil units and approximately 10 air changes of air from the central systems for ventilation.

Chilled water from the central Utility Plant will be piped to each laboratory pipe shaft and to the Computer Facility air handling units-for sensible cooling requirements. Oversizing the pipes will afford a large amount of future cooling capability as laboratory sensible-loads are increased.

\section{SPACE USE BY AREAS}

The Survey comprises four operating and three supporting Divisions. Since the operating Divisions need varying amounts of laboratory space, the building's variable height is achieved by stepping back the Laboratory floors and thereby decreasing their areas proportional to that of adjoining Administrative Areas. A full Laboratory floor contains 110,000 square feet, while a full Administrative floor contains 50,000 square feet. The Administrative Offices of each of the Survey's seven Divisions are thus accessible by vertical circulation to the Director's Office, with the Laboratories of each Division horizontally connected with the Administrative Wing. 
The Administrative Area consists of seven floors of office-type space, including conference rooms. The 270,000 net square feet of space is assigned essentially as follows:

\section{FLOOR ACTIVITY}

$\begin{array}{llcl}7 & \text { Director's Office } & 4 & \text { Survey Library } \\ \text { Conservation Division } & 3 & \text { Geologic Division } \\ 6 & \text { Administrative Division } & 2 & \text { Topographic Division } \\ & \begin{array}{l}\text { Publications Division } \\ \text { Computer Center Division }\end{array} & 1 & \text { Lobby, Survey Personnel Office } \\ 5 & \text { Water Resources Division } & \text { Ground } & \text { Cafeteria, Custodial Shops }\end{array}$

\section{LABORATORY AREA}

The Laboratory Area is a horizontal extension of the Administrative Area, the Laboratories associated with each Division being located on the same floor with and adjacent to the staff. A flexible laboratory environment is obtained by the assignment of scientists to individual lab-offices which will be grouped around the more complex backup laboratory facilities. The 276,500 square feet of space devoted to laboratories varies from the Water Resources Division's 29,000 square feet to Geologic Division's 133,000 square feet. The Laboratory Area will have six passenger elevators in three banks of two, a large freight elevator, and seven stairwells.

\section{MAP REPRODUCTION AREA}

The Map Reproduction Area consists of 107,000 square feet of space distributed on two floors. The first floor, which is separated from the Laboratory Area by a service roadway will house the Equipment Maintenance Section now located in the Acorn Building, Silver Spring, Maryland.

The second floor bridges the service roadway and extends 250 feet beyond the first floor. Due to the sloping site the extension of the second floor is essentially at ground level. This floor is a continuation of the second floor of the Laboratory Area and houses a 21,000-square foot Printing Plant and 56,000 square feet of Photographic and Cartographic Laboratory space.

\section{SPACE USE BY FLOORS}

The Cafeteria seating 600 people is located off the lower Lobby at ground level and has clear glass window walls. The Dining Area is a one-story structure projecting from the Administrative Area. It in- cludes a small Executive Dining Room. The Cafeteria roof is railed and serves as an observation platform. In the center is located a combination skylight and exedra which will seat about 100 people. 


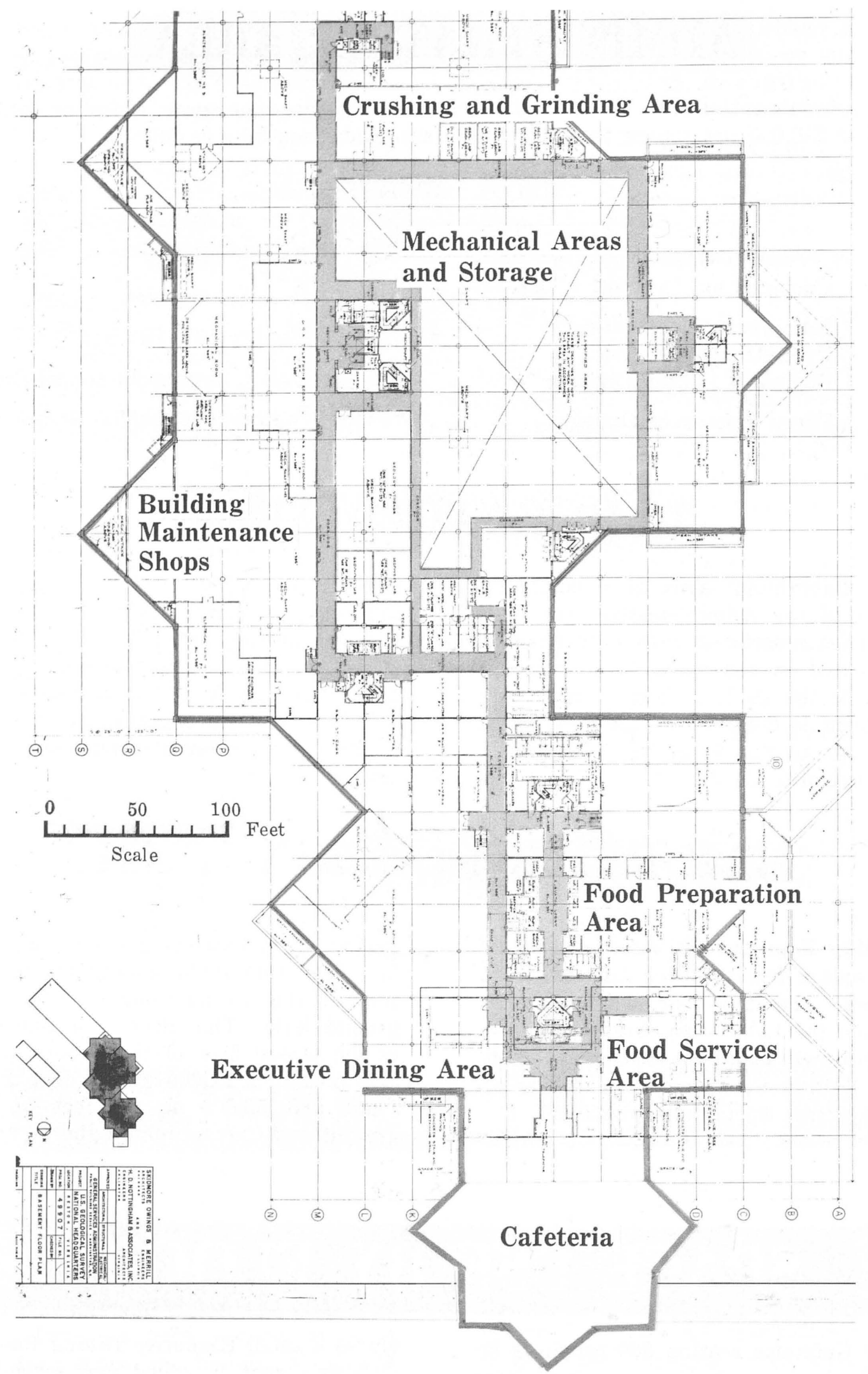

The ground level in addition to Food Services also contains Shops, Laboratories, Storage Space, mail room with vertical lift mail conveyor to all floors, telephone exchange and equipment, and large areas devoted to mechanical and electrical equipment. 


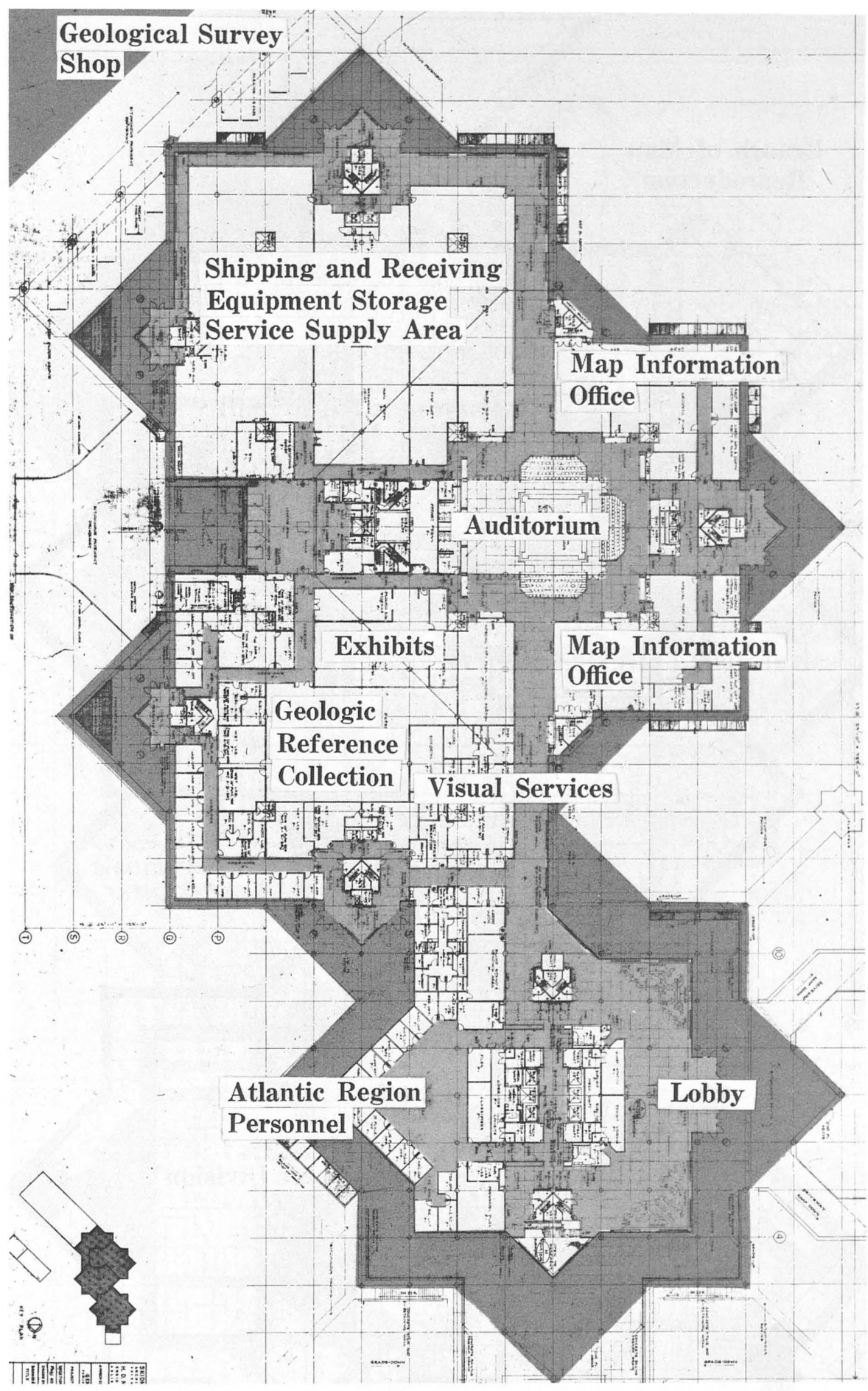

On the first floor a horizontal circulation system connects all entrances and elevator Lobbies allowing personnel to enter at the point nearest their parking place and proceed to the elevator core serving their station. Along the central corridor, which connects the main Lobby and reception center with the opposite end of the building, are areas for directory and Exhibits, vending machines, employee health unit, Credit
Union, map sales room, Auditorium-Conference Center, and rest rooms. Escalators connect the main and lower Lobbies.

The remainder of the first floor is occupied by Service and Supply operations, Exhibits and Visual Services Sections, Geologic Laboratories and storage for Paleontology and Stratigraphy, the Map Information Branch and the Branch of Personnel. 


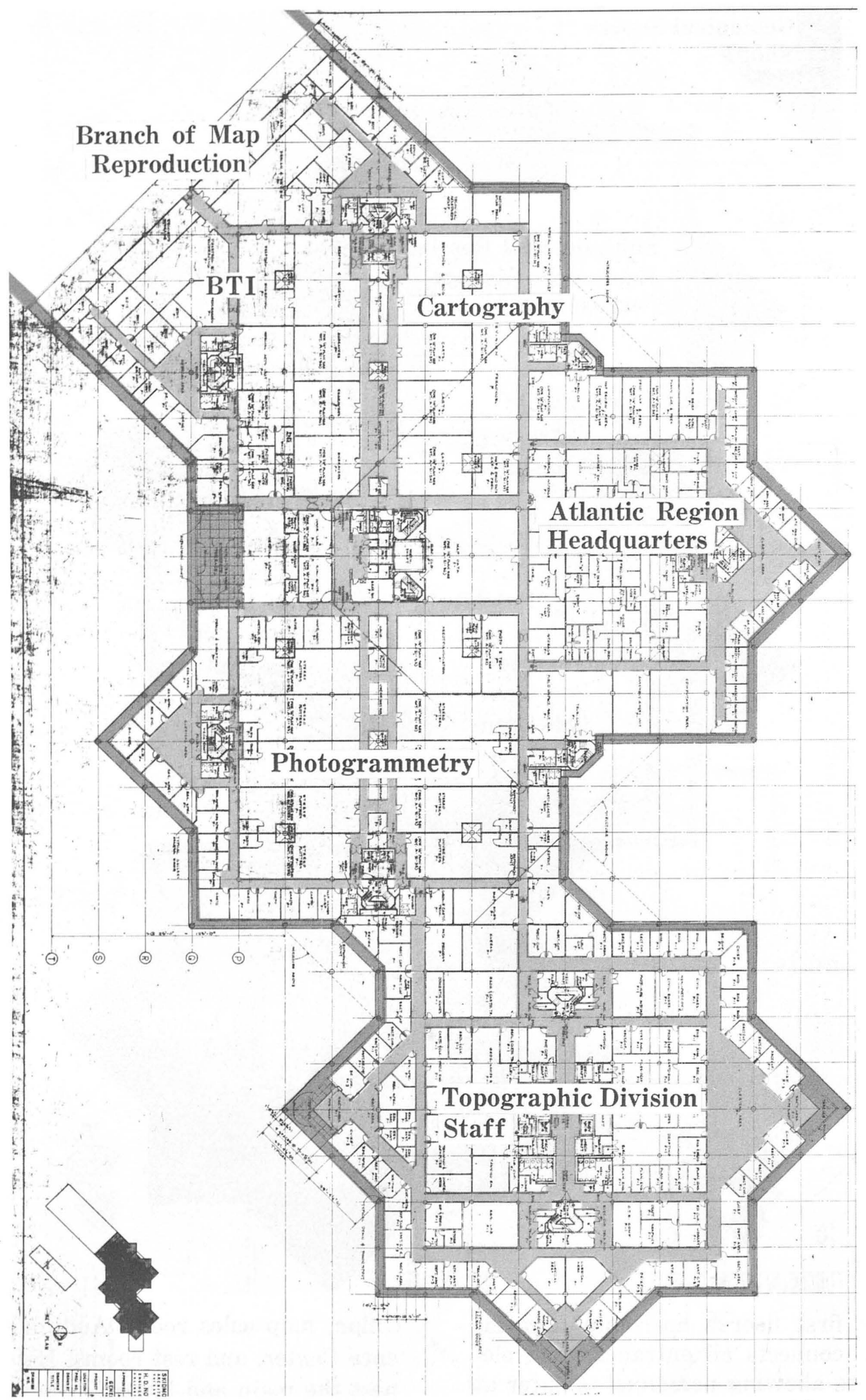

The second floor houses the Chief Topographic Engineer and his staff as well as the Atlantic Region Headquarters Office with its extensive Cartographic, Photogrammetric, and Photo-Reproduction Areas.

The Branches of Technical Illustrations and Texts of the Publications Division adjoin the Topographic Division Cartographic Labs-in the Laboratory Area. The Branch of Map Reproduction with its Photographic laboratories and Printing Plant occupy the entire 460 foot extension of the second floor. 


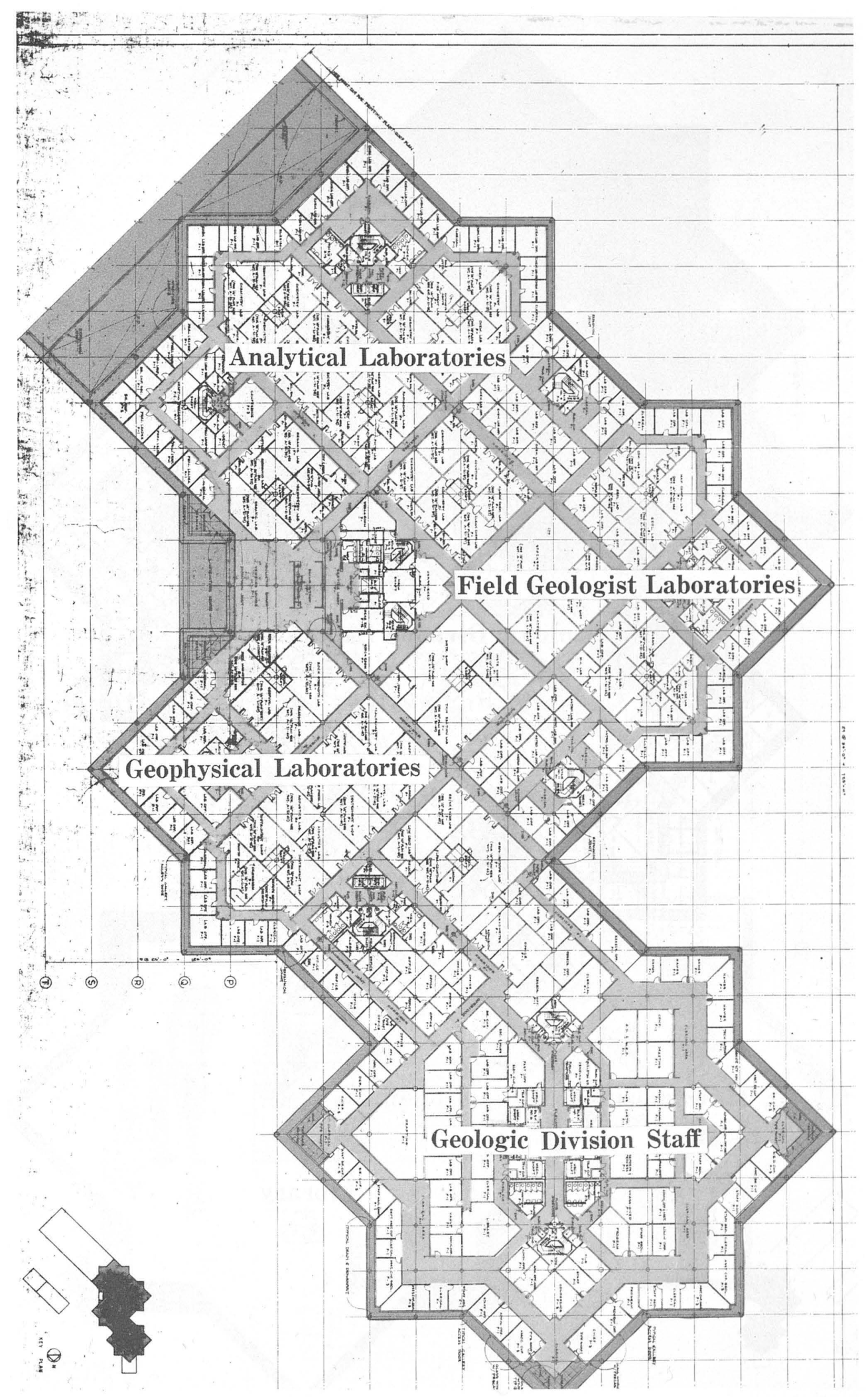

The third and fourth floors contain offices, lab-offices, and specialized Laboratories of the Geologic Division. The Chief Geologist and his staff are located on the third floor in the Administrative Area. Lab-of- fices of the subdivisions of Geochemistry, Geophysics and Environmental Geology occupy the perimeter of the third floor surrounding their highly specialized Laboratories and Shops. 


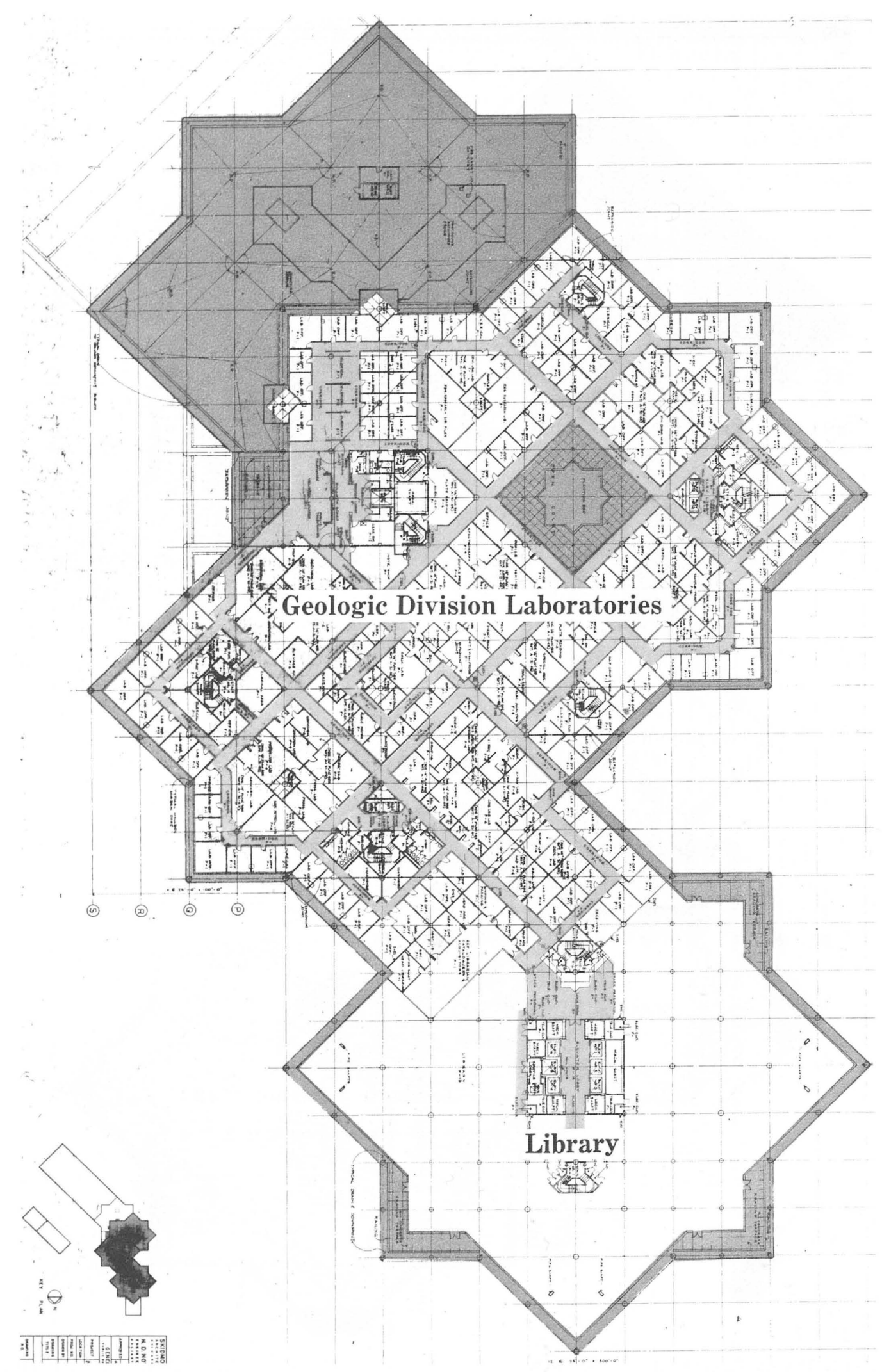

The Survey Library occupies 40,000 square feet; nearly all of the fourth floor Administrative Area.
The fourth floor Laboratory Area contains lab-offices and Laboratories of the subdivisions of Geochemistry, Geophysics and Mineral Resources. 


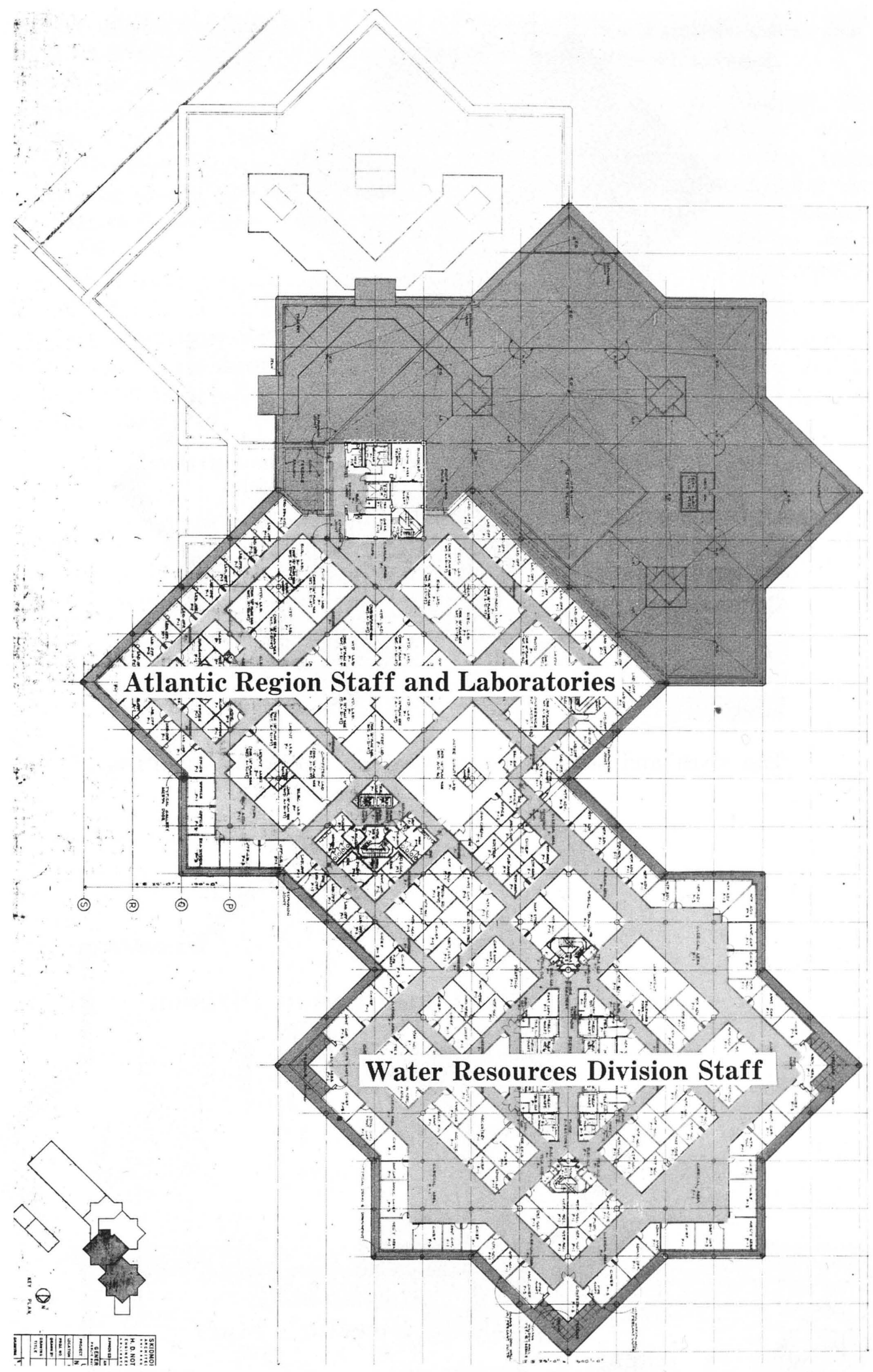

The fifth floor of the Administrative Area houses the Office of the Chief Hydrologist, his staff advisors, the Office of Research and Technical Standards, and the
Office of Water Data Coordination. The Regional Hydrologist, Atlantic Coast Region, and his staff with their lab-offices and Research Laboratories occupy the remainder of the floor. 


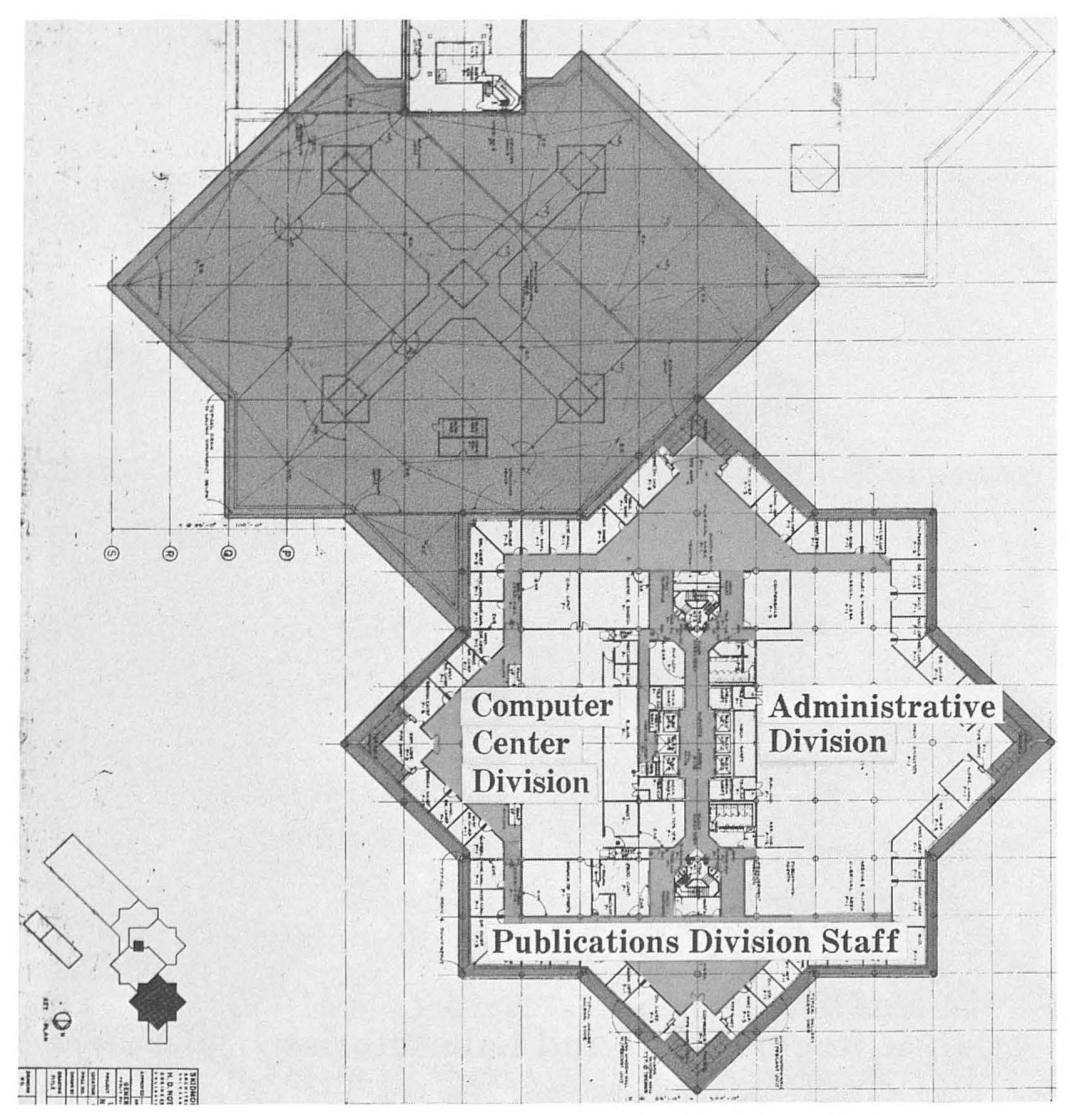

The sixth and seventh floors have no laboratory facilities.

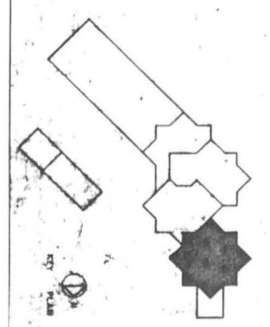

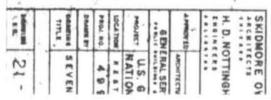

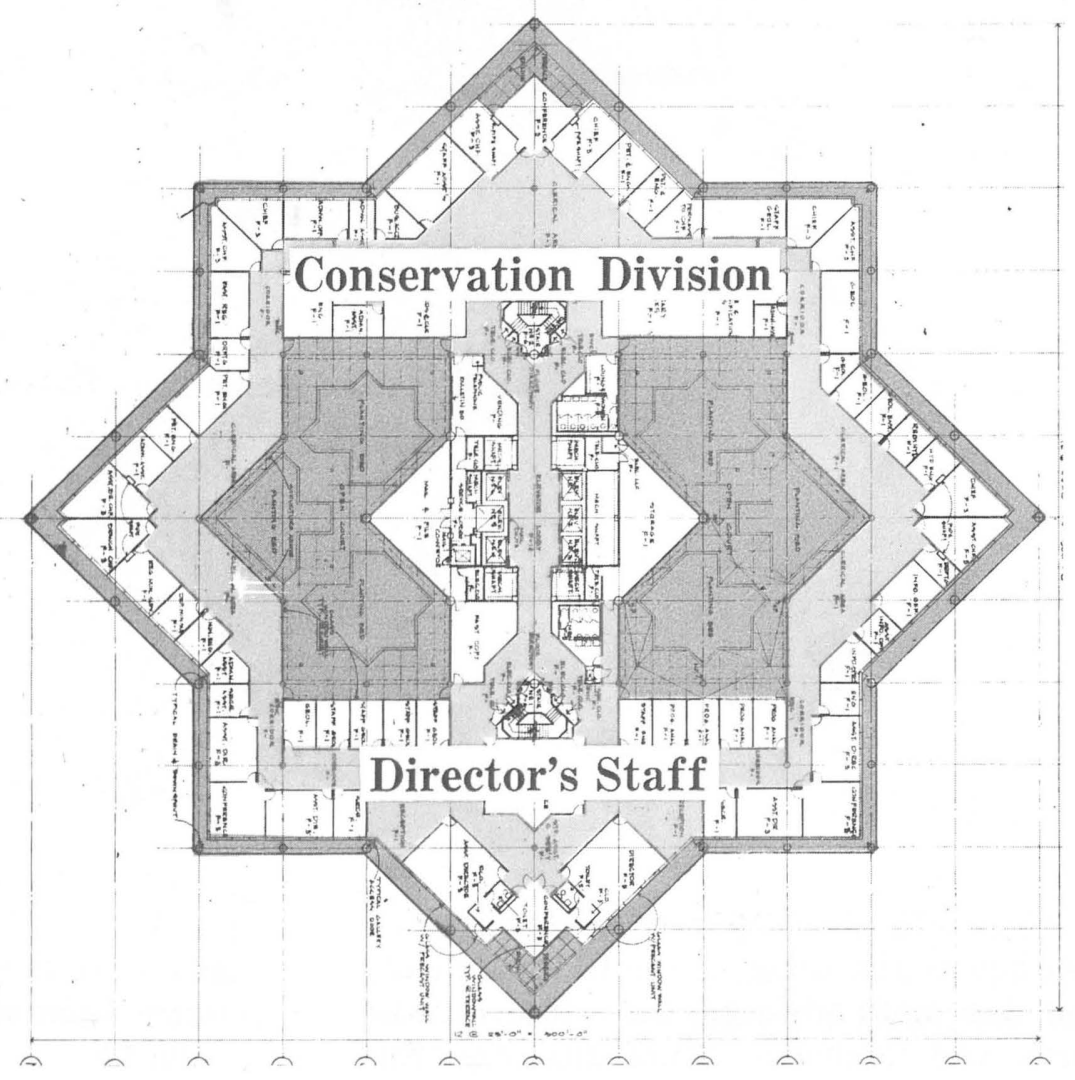


The Chief of the Publications Division and a small staff are located on the sixth floor to be readily accessible to the Director and the Division Chiefs. The Administrative and Computer Center Divisions share the remainder of the floor about equally.

The Director of the Geological Survey and his staff share the seventh floor with the Conservation Division.

The Survey's leadership in the natural resources field will be materially strengthened with the completion of this outstanding research and engineering facility. Bringing nearly all the Survey's 2,450 employees in the Washington, D. C., Metro- politan Area together under one roof will provide many advantages.

A health unit, Library, Auditorium, Cafeteria, Credit Union, and administrative functions such as personnel training, employee assistance, purchasing and supply distribution will be more readily available to all. The interchange of ideas through personal contacts will be stimulated.

Support services such as mail and messenger service, Shipping and Receiving, maintenance of equipment, photo labs, and printing and duplicating will be much more efficient.

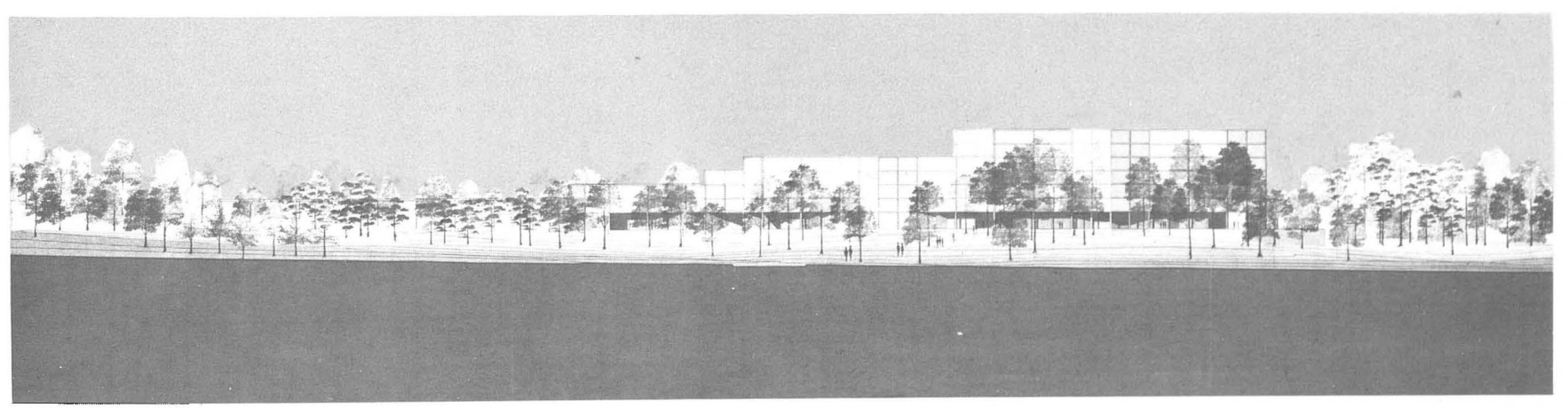


As the Nation's principal conservation agency, the Department of the Interior has basic responsibilities for water, fish, wildlife, mineral, land, park, and recreational resources. Indian and Territorial affairs are other major concerns of America's "Department of Natural Resources."

The Department works to assure the wisest choice in managing all our resources so each will make its full contribution to a better United States-now and in the future.

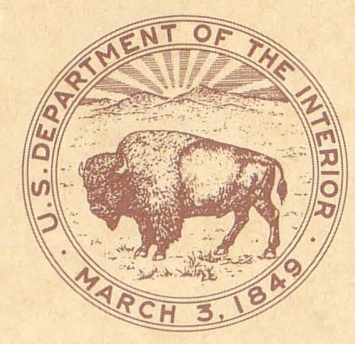

